\title{
WORD-OF-MOUTH PROCESSES \\ WITHIN A \\ SERVICES PURCHASE DECISION CONTEXT
}

by

Peter A. Voyer

B.A., Carieton University, 1984

A Thesis Submitted in Partial Fulfilment of the Requirements for the Degree of

Masters of Business Administration

in the

Faculty of Administration

Supervisor:

Harvir S. Bansal, PhD, Marketing

Examining Board: Devashis Mitra, PhD, Finance, Chajr

Deirdre Grondin, PhD, Marketing

Basu Sharma, PhD, IR/ARM/Law

External Examiner: Shelley Rinehart, PhD, Marketing, UNBSJ

THE UNIVERSITY OF NEW BRUNSWICK

April, 1999

Peter A. Voyer, 1999 
National Library

of Canada

Acquisitions and Bibliographic Services

395 Wellington Street Ottawa ON K1A ONA

Canada
Bibliothèque nationale

\section{du Canada}

Acquisitions et senvices bibliographiques

395. ne Wellington Otrawa ON K1A ONA

Canada
The author has granted a nonexclusive licence allowing the National Library of Canada to reproduce, loan, distribute or sell copies of this thesis in microform, paper or electronic formats.

The author retains ownership of the copyright in this thesis. Neither the thesis nor substantial extracts from it may be printed or otherwise reproduced without the author's permission.
L'auteur a accordé une licence non exclusive permettant à la Bibliothèque nationale du Canada de reproduire, prêter, distribuer ou vendre des copies de cette thèse sous la forme de microfiche/film, de reproduction sur papier ou sur format électronique.

L'auteur conserve la propriété du droit d'auteur qui protège cette thèse. $\mathrm{Ni}$ la thèse ni des extraits substantiels de celle-ci ne doivent être imprimés ou autrement reproduits sans son autorisation. 
This work is dedicated, in loving memory, to my father, Patrick; my hero and mentor, whose omni-present and most powerful spirit was always with me providing guidance, not only throughout this thesis, but also through all of my MBA and other life endeavours. 


\begin{abstract}
This thesis seeks to investigate the processes of word-of-mouth marketing within a services purchase decision context. Although word-of-mouth processes, as they influence service purchase decisions, are powerful and complex, they are not well understood. Nor does there exist an abundance of information within the research literature regarding this subject area. Accordingly, a proposed conceptual model has been developed which aims to explain the effects of salient constructs on the ultimate dependent variable: the influence of word-of-mouth on service purchase decision. The proposed model includes the independent variables of expertise (Sender's and Receiver's), perceived risk, tie strength and the extent to which the word-of-mouth message is sought. Based upon a review of the literature, nine distinct hypotheses are proposed. Findings resulted in all but two of the nine hypotheses being validated. Further, all of the aforementioned constructs affect, either directly or indirectly, the influence of Sender's word-of-mouth on the Receiver's purchase decision.
\end{abstract}




\section{ACKNOWLEDGEMIENTS}

I wish to acknowledge my mother, Edna, whose immutable love, kindness and unwavering encouragement was instrumental in the completion of this project, in addition to all academic and life accomplishments.

I also wish to recognize my supervisor, Dr Harvir Bansal, whose patience, dedication, guidance and professionalism made the entire production of this thesis, a most exiting and truly positive learning experience. He is one of the finest professors with whom I have ever had the pleasure of working.

I am deeply indebted to Major-General Bryan Stephenson, my mentor and councillor. The faith and trust that he placed in me was fundamental in facilitating the opportunity of pursuing MBA studies.

Appreciation is extended to all members of the business faculty within the University of New Brunswick who were effectual in stimulating my fascination and interest in the study of business. Particularly, Dr Norm Betts and Dr Mohamad Rashid, who were instrumental in my acceptance into the country's finest MBA programs; thank you. Very special appreciation is attributed to members of my advisory committee, Dr Basu Sharma, Dr Deirdre Grondin and to Dr Shelley Rinehart, for their constructive recommendations and guidance.

Lastly, gratefulness is extended to my wife Michelle and daughters Stephanie and Caroline whose love and understanding was stretched to the extreme while Daddy was busy working on this thesis in addition to his MBA studies. 
Dedication

Abstract

Acknowledgments

List of Tables vii

List of Figures viii

Chapter 1: Introduction 1

Chapter 2: Scope of the Investigation into WOM 4

$\begin{array}{ll}\text { Communications Model } & 4\end{array}$

Why do People Engage in WOM? 7

WOM: An Example $\quad 9$

$\begin{array}{ll}\text { Theoretical Foundations of WOM } & 10\end{array}$

WOM in a Services Contest 11

Literature Review 11

$\begin{array}{ll}\text { Services Context } & 12\end{array}$

Chapter 3: Conceptual Framework $\quad 15$

Proposed Conceptual Model $\quad 15$

$\begin{array}{ll}\text { WOM Actively Sought } & 17\end{array}$

$\begin{array}{ll}\text { Tie Strength } & 20\end{array}$

$\begin{array}{ll}\text { Perceived Risk } & 24\end{array}$

Sender's Expertise $\quad 26$

Receiver's Expertise $\quad 29$

Chapter 4: Research Design Methodology and Results 33

$\begin{array}{ll}\text { Methodology } & 33\end{array}$

Proposed Research Setting and Selection of Respondents $\quad \cdots-34$

$\begin{array}{ll}\text { The Survey Questionnaire } & 37\end{array}$

Scales $\quad 39$

Pretest Study $\quad 44$

Psychometric Properties of the Pretest Scales 45 
Conclusions from the Pretest $\quad 47$

$\begin{array}{ll}\text { Main Study } & 47\end{array}$

Demographics of Data Set $\quad 48$

Measurement Model $\quad 49$

Stage 1: Exploratory Analysis $\quad 50$

Stage 2: Confirmatory Analysis: Internal Consistency of Scales 54

Stage 3: Path Analysis $\quad 58$

Structural Models $\quad 58$

Summary of Results $\quad 60$

Chapter 5: Discussion $\quad 61$

Summarizing Conclusions Regarding Interpersonal Variables 64

Summarizing conclusions Regarding Non-interpersonal Variables $\quad 65$

Summary of Measurements and Salient Analytical Results 66

$\begin{array}{ll}\text { Managerial Considerations } & 67\end{array}$

$\begin{array}{ll}\text { Limitations and Avenues for Future Research } & 73\end{array}$

$\begin{array}{ll}\text { Chapter 6: Conclusion } & 75\end{array}$

Appendix

$\begin{array}{ll}\text { Appendix A: The Survey Questionnaire } & 76\end{array}$

$\begin{array}{ll}\text { Bibliography } & 84\end{array}$

Vita 


\section{LIST OF TABLES}

Table 1: Summary of pre-test preliminary statistical analysis.

Table 2: Respondents' education levels. 48

Table 3: Respondents' personal income brackets. 49

Table 4: Respondents' household income levels. 49

Table 5: A summary of salient measures attained from Stage 1 analysis. $\quad 54$

Table 6: A summary of Stage 2 analysis.

Table 7: Summary on the hypotheses for the structural part of the model. 60 


\section{LIST OF EIGURES}

Figure 1: A modified model base on the traditional communications model.

Figure 2: The relationship of interpersonal and non-interpersonal forces.

Figure 3: The proposed conceptual model.

Figure 4: Results of path analysis indicating path loadings and t-values.

Figure 5: Graphical representation of amount of search as function of expertise. 63 


\section{Chapter 1}

"Even thase deof to the brazging cries of the marketplace will listen to a friend"

(Anonymous)

\section{INTRODUCTION}

The study of marketing is one of the most fascinating and intriguing fields within the discipline of business administration. In essence, it is the "link" which connects a business organisation with the outside world. Whether considered as a process or as a philosophy, marketing encompasses many processes which, ultimately, address the many facets of exchange. Integral to the notion of exchange is marketing communications, which is concerned with the "sending and receiving of knowledge, ideas, facts, figures, goals, emotions and values...it is a ceaseless activity of all human beings, and therefore, also of all human organisations" (Smith et al. 1997, p.2).

Most of the popular managerial literature contends that the word-of-mouth (WOM) communications process is one of the most powerful forces in the marketplace (e.g., Henricks 1998, Marney 1998, Silverman 1997). Indeed, it tends to be highly persuasive and in turn, extremely effective (Bristor 1990). This is primarily due to the fact that consumers frequently rely on informal/personal communications sources (WOM) in making purchase decisions as opposed to more formal/organisational sources such as advertising campaigns. In WOM, the source (Sender) of the information generally has nothing to gain from the Receiver's subsequent actions (Schiffman and Kanuk 1997). 
One of the first studies attesting to the potential power of WOM was conducted by Amdt (1967a) who examined the effect of WOM on food product purchasing decisions. His main finding clearly indicates that positive WOM increases the likelihood of purchase while negative WOM acts to decrease purchase intentions. Within a services context, who hasn't asked a friend to recommend a reliable baby-sitter, dentist, auto mechanic or a favourite restaurant?

Further substantiating the power of WOM on purchase intentions was the research conducted by Bayus (1985), who also emphasised WOM's importance in purchase decision contexts. Indeed, WOM is often even more important than other direct marketing methods, such as the aforementioned commercial advertising campaigns.

WOM is an extremely complex phenomenon; considerably more complex than is readily apparent and commonly assumed. As Still et al. (1984) state, "consumer adoption of new products and services is determined to a large degree on individual consumption experiences connected by WOM through different social groups" (p. 344).

As indicated by many researchers, including Charlett and Garland (1995), there has been surprisingly little research conducted which has examined the effects of WOM communications on Receivers' (those who receive the WOM message) purchase decisions. In addition, most research documented in the literature is oriented toward product marketing and not services. WOM, however, is more important and influential within a services context than strictly just product marketing scenarios (Murray and Schlacter 1990; Zeithaml 1981). It is this consideration which has led to a greater curiosity of WOM effects on services purchase decision and hence, the subject area of 
this thesis.

This thesis will contribute to the research literature in several key areas. Firstly, very few other WOM research endeavours have focussed on the services purchase process. Secondly, no other known studies have examined the construct of the extent to which WOM information is actively sought within a services scenario. In light of these key differentiating factors, it is believed that this study will yield considerable knowledge to the field of services marketing.

The intent of this thesis is to investigate the WOM process, by viewing the Sender of the WOM message as well as the Receiver of it, within a condition of dyadic communication. Specifically, the actual influence that the WOM message has on the Receiver's service purchase decision will be empirically examined. In so doing, various mediating and moderating factors involved in the process will be considered. Accordingly, hypotheses have been formulated resulting in the development of a proposed model, which will be presented later within this thesis. This study will not examine implications associated with either positive or negative WOM. Instead, it will focus on the actual process involved, given the condition of WOM communication. 


\section{Chapter 2}

\section{SCOPE OF THE INVESTIGATION INTO WOM}

Prior to proceeding, it is important to definitively articulate the meaning and understanding of WOM as it will be used throughout this thesis. One of the most thorough and appropriate descriptions of WOM, comes from Schiffman and Kanuk (1997), who state that, "the key characteristic of WOM communication is that it is interpersonal and informal and takes place between two or more people, none of whom represent a commercial selling source that would gain directly from the sale of something. WOM implies personal, or face to face, communication, although it may also take place in a telephone conversation or within the context of a chat group on the Internet" ( $p$. 500).

Notwithstanding the above definition, there might exist situations whereby the source (Sender) of the WOM may be in a position to gain financially from the initiation of WOM. Several examples will later be considered which will suggest that the source of the WOM communications might be in a position to benefit (financially) from the transmission of WOM. However, the overall intent of the definition remains intact and will be upheld.

\section{Communications Model}

Communications is a central element in the way that people relate and cooperate with each other. It is the interpersonal event which is an integral component of society (Smith et al. 1997). Individuals not only send and receive information, but they do this 
by cooperation and ideally, understanding the message.

This thesis will view WOM as the flow of information through a dyad comprised of key actors (Sender and Receiver). This approsch, similar to that of Frenzen and Nakamoto (1993), is founded on the premise that the information flow will occur provided actors decide to cooperate during the transmission of the information. Hence, actors are required to cooperate in order to facilitate the information flow.

Initially drawing upon a basic conceptual communications model, within a dyadic context, it can be seen that the two main components are the Sender and the Receiver. The transmission of the WOM message is directed from the Sender to the Receiver. Following this, normally, is the Receiver's purchase decision, which invariably is either to purchase, or not to purchase, and may or may not be in accordance with the WOM message.

Therefore, it is proposed that a filtering process occurs which ultimately results in a purchase decision. This, cognitive filter functions within a "black box" in which certain forces work to influence the Receiver's purchase decision. It is within this "black box" that the proposed conceptual model will be presented and discussed later in Chapter 3. 
Diagrammatically, this process can be illustrated as follows:

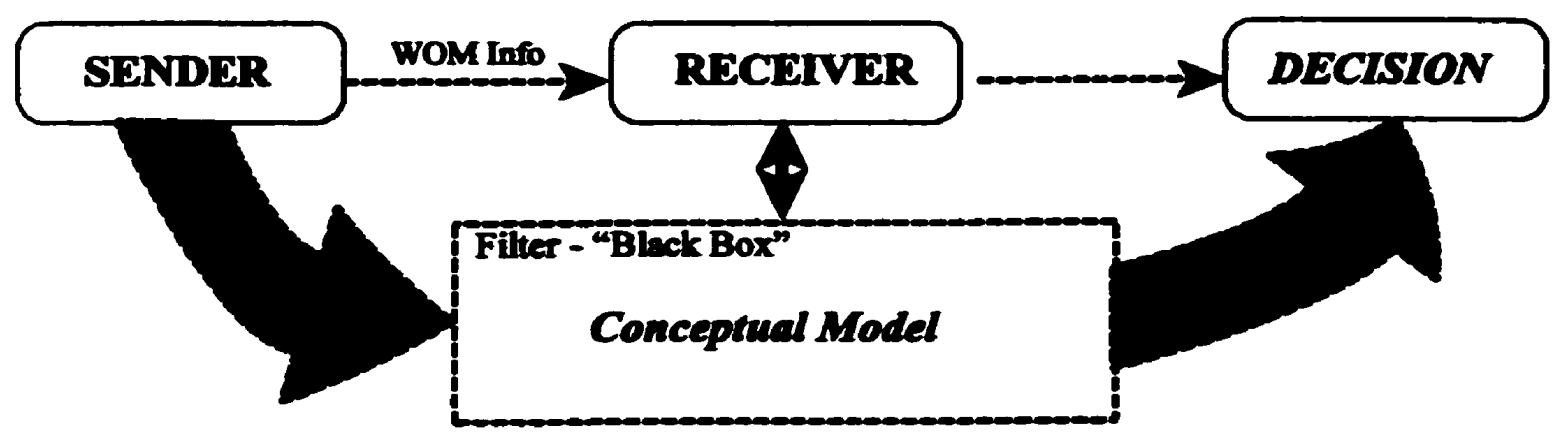

Figure 1. A modified model based on the traditional communications model of Lasswell (1948) (Duncan and Moriarty, 1998).

Use of the basic communications model in marketing is well documented. Duncan and Moriarty (1998) emphasise that the crucial and central role that communications plays is integral to marketing. Further emphasizing this importance, the researchers purpose that there exists a parallel relationship between marketing processes and the communications model. Moreover, they stress the contextual aspects of communications by indicating that relationships are integrally related to communications and therefore, one cannot be investigated without considering the other. They also stress the interconnection between the notion of exchange in marketing theory by suggesting its similarity to the notion of exchange in communication. Hence, the setting of the conceptual model of this thesis within communications underpinnings is not without sound academic basis.

Amdt (1967a) stressed communicative dimensions of WOM processes by stating that, "word of mouth is normally purposeful and serves important ends for the 
communicators [Sender and Receiver]. In some cases their motive for transmitting information is to be heipful to their friends. In other cases, word of mouth serves functions of ego-defence and dissonance reduction, or is a means of enhancing the status of the information-giver" (p.71). Ultimately, therefore, WOM can serve a variety of purposes, but the emphasis remains, that it is a key process of information transmission.

\section{Why do people engage in WOM?}

Many reasons exist for people attempting to solicit information via WOM. Consider for example, a military family who is posted to a new location. Upon arrival, dependents must seek new service providers in functional areas such as medical, dental, hair styling etc. How do they determine which service providers are the most suitable? They frequently solicit advice from friends, relations, or colleagues who have already lived in the area and who have established a set of service providers. For a military family, this process of attaining new service providers occurs after each new posting; generally every two to four years.

Motivation for soliciting WOM often varies as a function of types of service. Some services clearly bear greater amounts of risk than do others. For example, selecting a family physician is considerably more risky than choosing a suitable hair stylist or picking a good restaurant. The notion of risk and its impact will be considered later in this paper.

The literature acknowledges that many reasons exist for people to seek WOM information. Bristor (1990) categorized factors associated with WOM into three main classifications: individual; product; and situational. She reported that some people may 
prefer personal, noncommercial information, as opposed to alternative kinds such as impersonal and commercial information. Further, she mentioned that some people may tend to trust their friends' opinions over commercial sources which they likely perceive as being not as credible. As Smith and Swinyard (1982) suggest, people, in a vicarious manner, may use others' personal experiences as a substitution for their own experience or trial. This notion was also substantiated by Still et al. (1984).

Stressing individual factors, Amdt (1967a) suggested six primary motives for engaging in WOM: (1) altruism, the desire to help the Receiver make an appropriate purchase decision; (2) instrumental, the Sender originates and transmits WOM information with a particular purpose in mind, which may not be related to the message or to the well-being or the Receiver; (3) ego-defence, to project frustrations and dissatisfactions onto others or onto particular products or services; (4) interest, the more interested a person is in a particular service, the more likely that communication about it will ensue; (5) establish cognitive clarity, communication will likely result when an attempt is made to understand something; and (6) reduce cognitive dissonance, "the dissonant buyer can make his [or her] environment more consonant by actively persuading other people also to buy the product [or service] in question" (p.57).

Product or service factors include factors associated with risk, newness of the product and services characteristics. In an effort to determine information about a new product or service, WOM might be solicited, which could ultimately serve to reduce associated risk. 
Situational factors include the stage of the Receiver's purchase decision process, the availability of time, and the effect of substituting WOM information search for decision making. Often forces are at work over which the Receiver has no control.

\section{WOM: An Example}

The Financial Post, in a relatively recent article (1997), illustrated the power of WOM in a rare WOM-orchestration effort. Japanese advertisers, knowing the great weight of personal recommendations, especially when it comes to teenage Japanese school giris, have attempted to capitalize on WOM. These Japanese teenagers are known for their materialism, love of trends, and their mania for communication; many carry a pager and cellular phone. Normally, WOM is free and is impossible to arrange. However, in Japan, it can be arranged, for a price (using designated opinion leaders).

Agencies have been established with hundreds of teenagers in their employ, who receive a new product to try out and tell their friends about them. The logic is simple. Selected teenagers are given information or samples of a new product. They feel superior for knowing about something before the rest of the crowd, so they tell on average 50 of their friends and classmates about the "discovery". So, with a core group of 1.000 , WOM can spread to 50,000 or more. Information spreads more rapidly among the 15 to 18 -year old group than any other life stage. "The feeling of being "in the know", generated by exposure to a product before it hits the mass media can win over even the coolest 16year-old" (p.77). 


\section{THEORETICAL FOUNDATIONS OF WOM}

This examination into the processes of WOM will be pursued by considering salient constructs which may be categorized under the two principal rubrics of noninterpersonal forces and interpersonal forces. Therefore, three main relationships become apparent. Firstly, the effect of the non-interpersonal forces on the ultimate dependent variable; secondly, the effect of the interpersonal forces on the ultimate dependent variable; and lastly, the effects of non-interpersonal forces on interpersonal forces. Diagrammatically, this relationship can be depicted as follows:

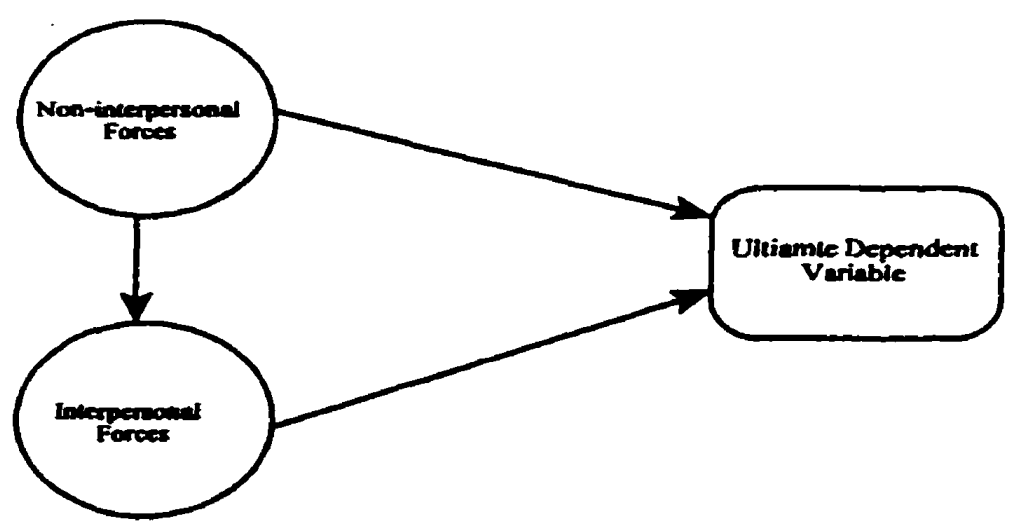

Figure 2. The relationship of interpersonal and non-interpersonal forces.

This approach to WOM has theoretical substantiation. Bristor (1990) emphasised that the development of WOM theory has adhered to an "individualistic paradigm which isolates people from their social context and thus is not well-suited for investigations of dynamic interactive phenomena such as word of mouth" (p.52). This suggests the 
emphasis on solely non-interpersonal forces. Furthermore, Bristor advanced a network approach to the study of WOM, explaining its relevance by stating, "the network approach [is] a promising altemative for word of mouth research because it explicitly recognizes the relationships that link members of a social system" (p.52-53). Hence, there exists a requirement to examine interpersonal forces within WOM models. Additionally, Amdt (1967a) suggested that, "word of mouth tends to flow through interpersonal channels based on shared interests, friendship or family" (p.71). Each of these items identified by Amdt will be individually examined later within this paper when discussing the construct of tie strength in Chapter 3.

Constructs such as Receiver's perceived risk, Receiver's expertise and Sender's expertise are non-interpersonal forces. However, WOM actively sought by Receiver and tie strength are interpersonal forces in which exchange takes place in a dyadic framework.

\section{WOM IN A SERVICES CONTEXT}

\section{Literature Review}

The research literature on WOM has traditionally been oriented along three principal streams (Still et al. 1984): (1) the consumer's decision process focus, which includes initial awareness of a product or service and finally ends in adoption; (2) a communications-oriented stream, integral to this approach is the contention that WOM information is diffused through a network, where the information is spread to others; and (3) a consideration of the WOM communications as a "more general and indirect influence" (p. 336). The network approach, within a communications framework, will be the selected treatment for this examination of WOM processes. 
While there exists much opinion regarding the power (and usefulness) of WOM, there is surprisingly little empirical research which exists that examines "procedural" aspects of WOM. The literature is, therefore, not rife with WOM research. Although steadily gaining in popularity, the subject has had very humble investigative beginnings. For example, the Journal of Marketing, from the mid 1950s to the late 1960s had published only one article dealing exclusively with the issue of WOM (Amdt 1967a).

Despite these modest beginnings, in recent years most WOM research has almost exclusively focussed on product-oriented issues (Murray 1991). Remarkably little research attention has been devoted to the behaviour of the service consumer. This is surprising since WOM influences tend to be stronger in services, given their (services) intangibility and higher associated risk (Murray and Schlacter 1990).

\section{Services Context}

Conducting WOM research within a services context is unique and sheds an interesting light on the issue. Indeed, seldom in empirical research has WOM ever been examined exclusively within a services context. The basic tenants of services marketing consisting of intangibility, heterogeneity, simultaneity of production and consumption, and perish-ability serve to delineate the marketing of services from the marketing of goods (Zeithaml and Bitner, 1996).

Among the unique characteristics of services which have significant impact on the study of WOM is that of intangibility. The WOM process offers special solutions to the "problem" of intangibility of services. A stimulation of positive WOM can help to overcome a service's problem of credibility. Offering a month's free rent to a customer 
who brings another customer to the business, is an example of an attempt to stimulate positive WOM communications. Likewise, in an attempt to engage in post-purchase communications, follow-up, thank you letters are frequently sent by service providers. Bristor (1990) provided a succinct description of services aspects as follows:

three other product characteristics normally associated with services, intangibilin, few search qualities and low comparability, make them natural candidates for word of mouth (Ziethaml 1981). Because services are intengible and thus my be difficult to fully understund before their delivery/consumption, word of mouth is often utilized to obtain needed information from an experienced user of the service before, for example, the use of real extate or payroll processing services. Also, since services are often high on experiential, but low on search qualities, word of mouth can help a consumer make a pre-purchase cvaluation, for example of a doctor, hair stylist, or restaurant. Finally, services are often difficult to compare because the firm and the brand are often synonymous, as in the case of courier services or health clubs.... Thus, an effective way for a customer to compere alternatives across companies is to engage in word of mouth with one or more knowledgeable others (p.56).

As indicated, the study of WOM within a services context reflects an atypical alternative to the traditional study of most marketing concepts, that is, within a product marketing context. This is particularly important when one considers that every product has a services marketing component associated with it.

Aggrandizing the above concept to services, the normal (product) marketing mix of product, price, place and promotion can be expanded to include physical evidence, participants and process (Bitner, 1991). Therefore, those who are involved in the marketing of services, have considerably more challenges than typically do those engaged primarily in product-focussed marketing. Perceptions of these additional variables are particularly prone to WOM opinions.

Documented in the literature is the importance of WOM in shaping expectations of service (Zeithaml and Bitner 1996). Due to its perception of being unbiased (limited to 
the extent that there is no monetary nor commercial gain to be attained by the Sender of the WOM message), there is an added degree of importance associated with WOM as it is used as an information source in services that are dificult to evaluate. WOM, therefore, becomes especially important within this context.

It is apparent that there exists tremendous potential for conceptualizations and new directions in WOM marketing. In comparison to other areas of WOM research (communications), the workings of WOM on the purchase of services have not been extensively attended to within academia. This in turn, has resulted in relatively few empirical examinations of WOM processes in marketing, as was previously mentioned.

In light of the above, this thesis will differentiate itself from previous work by considering and testing constructs, many of which have not before been considered within the literature, as they relate to the marketing of services. 


\section{Chapter 3}

\section{CONCEPTUAL FRAMEWORK}

\section{PROPOSED CONCEPTUAL MODEL}

The Gilly et al. (1998) dyadic study of the interpersonal information search process has formed the rudimentary basis for the proposed model which will be employed within this thesis. While extremely informative, the Gilly study, however, is somewhat limited for several reasons. Primarily, it is restricted to the consideration of product purchase and, therefore, no consideration is made of the impact of factors on the purchase of services. As mentioned, intangibility of services typically results in higher associated perceived risk, which is deserving of dedicated empirical examination.

A significant consideration is devoted to homophily within Gilly's research, however, its focus is essentially centred upon demographic conditions and differences. The component of "emotion" is not taken into account. The Gilly study did not consider tie strength although the effect of homophily was incorporated. Additionally, the Gilly model did not consider the variable of risk, nor how actively sought WOM, as a variable, affects influence of the Sender's WOM. Hence, the proposed model contained herein, has significantly expanded the Gilly study to include additional variables, as well as considering the effects of these constructs within the context of services purchase.

As Rogers (1983) indicates, homophily is the extent to which persons are similar with respect to attributes which are demographically descriptive. Such attributes are: age, gender, education and social status. People who are rated highly in homophily tend to "flock together." Underscoring the relevance of this notion, are Brown and Reingen 
(1987) who stated that, "a fundamental principle of human interaction is that people tend to interact with others who are like themselves" (p.354). So, by extension, the notion of tie strength, which describes the "social binding" that exists between people should be examined.

As has already been emphasized, WOM within a services context is of particular importance. Several prominent researchers have stressed the importance of expertise, risk, tie strength, and the degree to which the WOM message is actively sought, as being particularly salient and worthy of future investigation (e.g., Brown and Reingen 1987; Frenzen and Davis 1990; Duhan et al. 1997; Murray 1991; Mitchell and Dacin 1996; Arndt 1967a; Still et al. 1984). Due in large measure to these recommendations as indicated in the literature, this examination will address the impact of these key variables on services purchase decisions as proposed in the conceptual model.

Further, in addition to the aforementioned unique WOM considerations which have not been examined in the research literature, this thesis will consider the variable of Receiver's expertise in both contexts of direct and indirect effect on the Sender's WOM influence on the Receiver's purchase decision. 
The proposed model is diagrammatically depicted as follows:

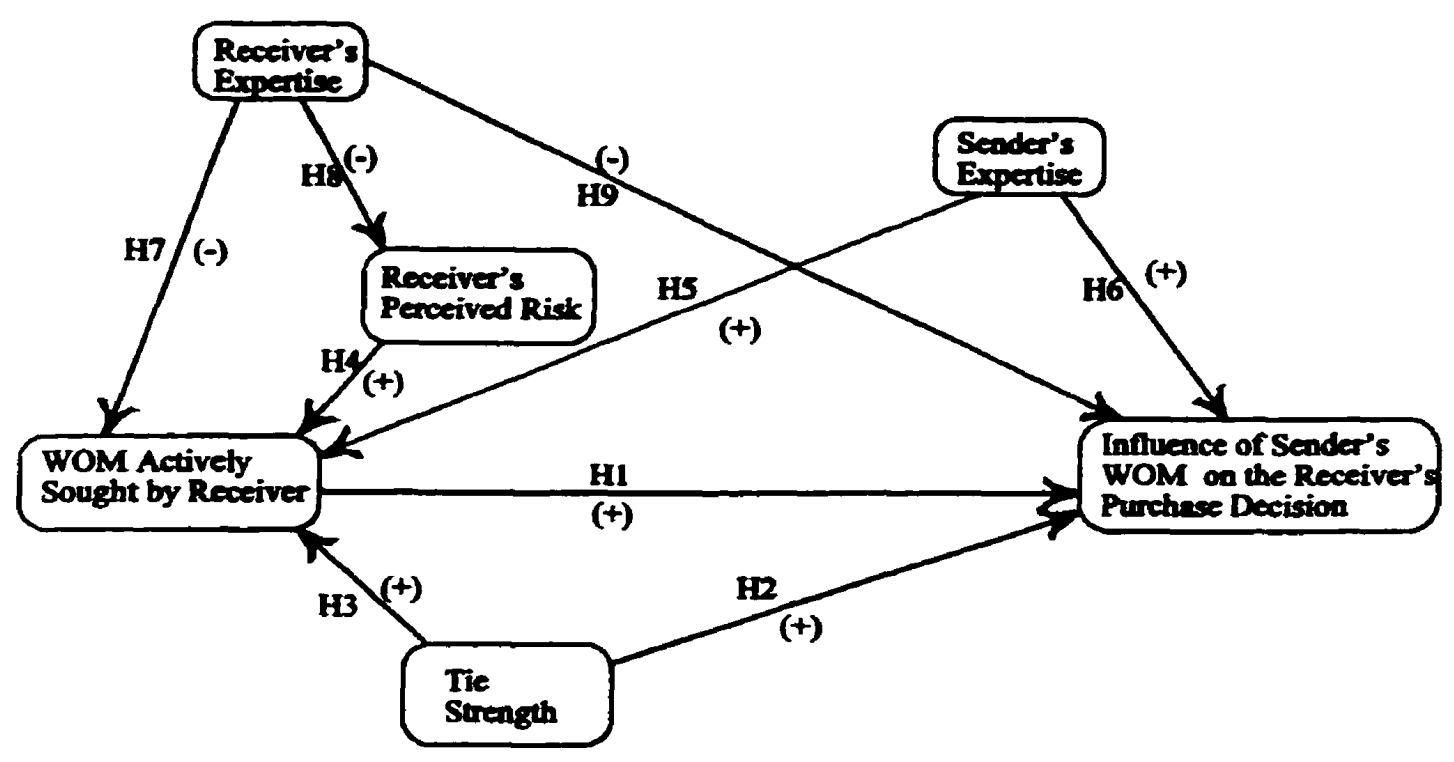

Figure 3. The proposed conceptual model indicating the constructs to be tested.

\section{WOM ACTIVELY SOUGHT}

Actively seeking WOM is construed as being the process of vigorously seeking and ultimately attaining a WOM message. It is understood to be essentially attained by purposeful design and effort. Additionally, associated with the actual process of actively seeking WOM, is selective exposure to the WOM message which, in turn, results in the consumer being more predisposed to the WOM message (Amdt, 1968).

A continuum may be considered whereby the degree to which WOM is actively sought ranges from low to high. On the low end of the continuum, the attainment of WOM may be construed as an unplanned or unintended receipt of information. Such information could be received when engaged in a conversation. A Sender, by chance, relates information to the Receiver regarding some issue of interest, such as the fine 
services he/she received from a particular hair stylist or auto mechanic. This type of information attainment can be contrasted against a more active search for information. For instance, at the opposite extreme of the continuum, a Receiver, knowing that he/she must undergo heart surgery, might very aggressively and actively seek information regarding the professional attributes and qualifications of several cardiovascular surgeons who potentially could fulfill his/her requirements. To do this, the Receiver might actively contact friends, family, and others who could be in a position to provide useful information regarding the subject of the decision to be made.

Emphasizing the communicative dyad in which the WOM processes occur, Amdt (1967a) stated, "the communicators and receivers of word of mouth are active, independent participants in the mass communications process. Receivers often initiate product conversations by asking communicators for information. Communicators play an active role by filtering and interpreting mass media information" (p.71). The Receiver's action of seeking WOM information is hypothesized to be an important element of the WOM process.

The degree to which a Receiver actively seeks WOM is likely to be connected with his/her motivation. Bristor (1990) indicated that individual factors such as certain types of information, personal motives and involvement levels can motivate WOM. Product factors such as high product involvement, message involvement situation or other-person involvement levels are also important motivators of WOM (Dichter 1966). 
Additionally, as previously mentioned, Bristor (1990) emphasised the importance of the following key factors in WOM motivation:

a. stage of the decision process - WOM is often used during pre-purchase (search) decision making. During post-purchase, it can also be used in an effort to reduce cognitive dissonance. In addtion, it is frequently used when a consumer has had a negative experience;

b. type of information available - when little or no information is available prior to a purchase decision or when there is no advertising used;

c. availability of time - when time is short there may be more engagement of WOM since it is a fast way of determining information needed for a purchase decision; and

d. situations for which WOM can be substituted for decision making instead of going through the decision making process for a new television, the Receiver could simply ask a friend who recently went through the same decision process for a recommendation.

In situations which are characterized by high uncertainty, WOM information is particularly sought (Amdt 1967a). High uncertainty exists when particular service characteristics are not known and correspondingly perceived risk is also high.

A logical implication resulting from this active search for WOM is an associated increased level of reception of the WOM message. That is, it is likely that a WOM 
message which is actively sought, will have a greater impact upon the dependent variable, the influence of the Sender's WOM on the Receiver's purchase decision, than a WOM message which is passively attained and was not received as a result of actively seeking. Thus, the following proposition may be drawn:

H1: The greater the extent to which the WOM is actively sought by the Receiver, the greater the influence of the Sender's WOM on the Receiver's purchase decision.

\section{TIE STRENGTH}

WOM communication occurs within a relationship. Whether the relationship is short, shallow and fleeting or, at the other end of the spectrum, firmly established, deeplyrooted and long-lasting, it can be logically postulated that all WOM transactions occur within some social relationship in which interpersonal forces are at work. A WOM network is, "a social network consisting of a set of people who engage in word of mouth, plus the relationships between them" (Bristor 1990, p.65). The relationship between people is essentially a force that works to bond them. A representation of this bond is tie strength. Hence, the construct of tie strength is integral to the examination of the principal rubric of interpersonal forces.

In describing tie strength, Duhan et al. (1997), state that "WOM recommendation sources can be categorized according to the closeness of the relationship between the decision maker and the recommendation sources, or the "tie strength" (Brown and Reingen 1987). The tie strength of a relationship is defined as strong if the source is someone who knows the decision maker personally" (p.284). 
The literature supports the aforementioned notion. As Money et al. (1998) state, "tie strength is a multidimensional construct that represents the strength of dyadic interpersonal relationships in the context of social networks" (p.79). Amdt (1967a) classified the nature of the ties between participants involved in a communicative dyad. He identified three main bases for WOM networks as: (1) common interest; (2) friendship; and (3) family. Common interest, he postulated, was needed in order for transmission of information to occur between two people. Failing the presence of this condition of shared interest, the information would not be transmitted. Of friendship, Amdt acknowledged the difficulty of distinguishing the two items by stating, "it is difficult to separate the effect of shared interest from the effect of friendship....usually friendship and common interests go together and it is possible that a chicken-and-egg problem exists" (p.61). Notwithstanding this, he indicated that friendship performs a linking role between people and therefore implies that a channel of communication exists. Lastly, on the item of family, Arndt suggested that, "kinship is the basis for perhaps most face-to-face communication. The voting studies reaffirm the role of the family by demonstrating strong tendencies of uniformity of opinion within each family unit" (p.63).

Summarizing his findings, Amdt (1967a) stated that channels of communication may be interpreted as serving an enabling or facilitating role in the WOM process. He suggested that before these channels can be activated, motivation sufficient for transmission must be present. Therefore, as will be discussed later, the construct of WOM actively sought by the Receiver becomes worthy of consideration.

Extending Arndt's notion of networks, Bristor (1990) viewed networks as integral 
to the study of WOM by stating that, "the network approach, is a promising altemative for word of mouth research because it explicitly recognizes the relationships that link members of a social system" (p.52-53).

It is, therefore, fitting to closely examine the relationship between the two dyadic components, the Receiver and the Sender, by considering the construct of tie strength. Granovetter (1973) considered the strength of ties by stating that it should satisfy the following definition, "the strength of a tie is a combination (probably linear) of the amount of time, the emotional intensity, the intimate (mutual confiding), and the reciprocal services which characterize the tie" (p. 1361).

It was indicated by Frenzen and Nakamoro (1993) that social context is an important aspect involved in WOM communications. Specifically, in their study, the researchers determined that social context (and information characteristics) appeared to influence individual WOM transmission decisions. The researchers corroborated the importance of the notion that the flow of information between actors, through a social network, is dependent upon decisions of the actors to cooperate when transmitting information. Additionally, they recognized the significance of the structure of the relations which connect the actors together.

To a limited extent Gilly et al. (1998) explored the fundamental basis of this construct by using the concept of homophily. Predominantly an indication of demographic variations, homophily, within this thesis, is extended to tie strength. This facilitates exploration of the inherent interpersonal dimensions of the construct which are closeness, intimacy, support and association (Frenzen and Davis 1990). 
Homophily does not answer the question of the Receiver's information source, rather the construct of tie strength addresses this concern. As will be discussed later in detail, this notion is of particular importance to groups in which high homogeneity exists and consequently have high homophily. Extending this precept, therefore, within a WOM scenario, the strength of tie could impact upon the influence of the WOM message on the Receiver's purchase decision.

The work of Brown and Reingen (1987) has provided instrumental insights into the notion and effects of tie strength. Specifically, the researchers suggested that strong ties bore greater influence than weaker ties.

Hence, the following hypothesis is submitted:

H2: The greater the strength of the tie between the Sender and the Receiver, the greater the influence of the Sender's WOM on the Receiver's purchase decision.

Additionally, it can be surmised that the strength of the tie will also affect how vigorously the WOM will be actively sought by the Receiver. Intuitively, it can be postulated that typically, when tie strength is high, the Receiver would attribute a prodigious level of credibility to the Sender. Also, in a high tie strength scenario, the Sender and the Receiver could likely be in close physical proximity to each other (or be in contact via Internet or telephone) and thereby facilitate actively seeking WOM information. Information from strong ties is also likely to be attained with marginal effort.

Brown and Reingen (1987), hypothesized that active information seeking is more 
likely to occur from strong-tie than weak-tie sources (Senders) of referrals. The researchers argued that when a strong tie exists between the Sender and the Receiver, the two are probably more familiar with each other than are those who are in a "weak-tie" dyadic condition. It is, therefore, believed that this strong-tie scenario results in a more easily facilitated search for WOM information. Moreover, Bristor (1990) corroborated this reasoning.

Applying the foregoing reasoning to this WOM scenario, it could be thought that when tie strength is high, as is typically the case with members of the same family, Receivers would be more active in seeking information from their "high-tie" Sender than others with whom there exists a "weak-tie" relationship. Notwithstanding, it could be reasoned that members of the same family could know what information is required by other members who might be in a Receiving role and thereby preclude the requirement of actively seeking additional (WOM) information.

Therefore, in light of the above, the following hypothesis is presented:

H3: The greater the strength of the tie between the Sender and the Receiver, the greater the WOM will be actively sought.

\section{PERCEIVED RISK}

Andt (1967a) provided the underlying basis for this examination of risk. As Arndt (1967a) indicated, Cunningham (1965) initially described risk in terms of two primary components: importance and uncertainty. Although somewhat dated, his approach to this construct serves as an initial point needed to expand this examination. Further, notwithstanding the fact that Amdt's examination was oriented solely to 
products, it still provides a useful basis from which to further consider risk as it relates to services purchase decisions.

Amdt (1967a) outlined several salient points regarding the effect of risk. He indicated that the subject of the WOM was instrumental in the level of perceived risk. For instance, he stated that the associated level of perceived risk with headache remedies was higher than that associated with fabric softener and dry spaghetti. Transposing this premise into a services scenario, it can be surmised that since some services bear higher levels of perceived risk, medical care would likely have higher associated risk than the selection of a favourite restaurant, for instance.

Further, Amdt (1967a) stated that, "word of mouth activity was higher, the higher the perceived risk" (p.31). In an effort to reduce their risk, consumers frequently attain information via WOM regarding the product or service in question. Furthermore, Amdt (1967b) found that people who perceive higher risk tended to more actively seek WOM information than those who perceived risk to be lower.

Although Amdt (1967a) established the basis for examination of risk within a WOM scenario, relatively little research has been conducted since his landmark WOM study. Notwithstanding, however, Zeithaml and Bitner (1996) emphasized the importance of this important construct.

Many researchers attest to the unique aspects of services, most notably Zeithaml and Bitner (1996), who have emphasised the role of risk in the service encounter. Specifically, the researchers indicate, that there is an apparent greater level of risk associated with the purchase of services, primarily since services are intangible, non- 
standardized and usually sold without guarantees and warrantees. The researchers also state that comparatively little is known about the process of service pre-purchase information gathering as it relates to WOM. The contention that there is greater perceived risk associated with services, as opposed to products, was further reinforced by Murray and Schlacter (1990).

Perceived risk is a formidable force in which several strategies exist to contend with it. Of these strategies, the seeking and attainment of WOM is salient. Murray (1991) reported that WOM was the most important means of attaining risk-reducing information and creates even a greater impact on consumers, largely due to clarification and feedback opportunities. Reinforcing this was Still et al. (1984). They contend that most existing literature reports that the influence of WOM on purchase decisions is less dramatic in a low-risk scenario as opposed to its more influential effects in a high-risk purchase situation.

Thus in light of the above, the following hypothesis may be considered:

H4: The greater the perceived risk of the service, the greater the extent to which the WOM will be actively sought by the Receiver.

\section{SENDER'S EXPERTISE}

Expertise, as described by Bristor (1990), is, "the extent to which the source is perceived as being capable of providing correct information, and expertise is expected to induce persuasion because receivers have little motivation to check the veracity of the source's assertions by retrieving and rehearsing their own thoughts" (p.73).

According to Alba and Hutchinson (1987), expertise is defined as, "the ability to 
perform product-related tasks successfully" (p.411). Further, the researchers use the term, consumers' expertise, in a very broad sense that includes both cognitive structures (eg. beliefs about a product) and cognitive processes (eg. decision rules for acting on those beliefs) required to perform product-related tasks successfully.

A Sender of a WOM message can be said to possess a high degree of expertise, from the Receiver's perspective, if by virtue of, "his or her occupation, social training, or experience is in a unique position" (Schiffman and Kanuk, 1997, p.335). Essentially, a Sender's unique position facilitates high expertise.

From an intuitive perspective, it can be postulated that the Sender's expertise affects how actively the WOM message is sought. If the potential Receiver of the WOM information wishes to seek information, he/she would stand to gain significantly more from a source who is perceived as being knowledgeable in the area in which the WOM information is being sought. This gives rise to the notion of information asymmetry.

According to the concept of information asymmetry, information is disproportionally, or unevenly, distributed with some people possessing more than others. Those with the least amount of information will attempt to attain needed information from those who they perceive as possessing a greater amount of information than themselves.

Specifically, if the Sender's expertise is high, the Receiver, in attempting to attain information via WOM, will likely more actively seek the information from a Sender who is perceived as having a high level of expertise. Conversely, it can also be purported that if the Sender's level of expertise is perceived (by the Receiver) as being low, he/she (the 
Receiver) would be less inclined to seek information from that Sender.

The positive relation between the Sender's expertise and the extent to which a Receiver will actively seek WOM from that Sender, was articulated by Gilly et al. (1998). To quote, "[Senders] who have greater expertise...will be depended on more heavily by information [Receivers] than will less expert non-leader [Senders]" (p.85). Hence, it can be hypothesized that Sender's expertise and how actively sought it is, is positively linked. In light of the above, the following hypothesis is submitted:

H5: The greater the Sender's expertise, the greater the extent to which the WOM will be actively sought by the Receiver.

In addition to the likely mediating role of Sender's expertise on how WOM is actively sought by the Receiver, another effect must be considered. Namely, the impact that the Sender 's expertise might have on the influence of Sender's WOM on the Receiver's purchase decision.

If an expert Sender's WOM is highly sought, then that WOM could reasonably be expected to have an influential impact on the Receiver's purchase decision. This premise was validated by Gilly et al. (1998), when they reported strong support for the contention that Sender's expertise positively affects the influence that it has on the Receiver's purchase decision.

Mitchell and Dacin (1996), in their study on expertise, found that those persons who were highly ranked in expertise were also likely to possess greater awareness and knowledge regarding product alternatives available in the market. Additionally, experts are more likely to store information about their higher level of knowledge and can infer 
performance from the information. This is useful for the Receiver in a services purchase context where reliance upon experts' WOM for knowledge becomes important. By logical extension, therefore, an expert's WOM message would have a significant impact on the Receiver's purchase decision.

In light of the above, therefore, it can be postulated that expertise may play a significant role in the overall WOM process. Thus, the following hypothesis is advanced:

H6: The greater the Sender's expertise, the greater the influence of the Sender's WOM on the Receiver's purchase decision.

\section{RECEIVER'S EXPERTISE}

The Receiver's level of expertise could have far reaching repercussions within the model. It could not only impact upon purchase decision, but also upon the Receiver's perceived risk, as well as how actively the Receiver will seek WOM information.

Research has established a relationship, within a product context, between level of expertise and the extent to which those seeking information will engage in active search for the target information. Thus, there exists a link between knowledge and experience (taken as a proxy for expertise) and the search for information.

Brucks (1985) reports that a number of studies have suggested a negative relationship between the amount of experience (as mentioned, this paper uses experience as a proxy for expertise) of an information seeker and the degree to which he/she conducts an external search for information. For substantiation, Brucks cites Anderson et al. (1979); Katona and Mueller (1955); Moore and Lehmann (1980); Newman and Staelin (1971, 1972); and Swan (1969). In an effort to explain this, Brucks suggests several key 
explanations. Firstly, a Receiver who possesses a high level of expertise is not in need of additional information and therefore makes little, if any, effort to expand his/her search. Another explanation contends that, "experienced consumers perform more efficient (thus abbreviated) information searches because they know which attributes are the most useful for discriminating between brands and can more quickly determine which alternatives are inferior (p.3). Alternatively, Brucks reports that other studies (eg. Johnson and Russco 1984; Punj and Staelin 1983) have postulated that prior knowledge encourages information search by enabling the Receiver (information seeker) to process information in a faster and easier way than if he/she possessed little expertise. The findings, therefore, are inconsistent regarding this relationship.

Notwithstanding this connection, however, there appears to be two principal streams of thought regarding the directionality of the relationship. Some empirical evidence seems to suggest a positive or curvilinear relationship between the two constructs. On the other hand, expanding this issue, Gilly et al. (1998) points out, "the preponderance of the evidence supports a negative relationship for information" (p.86). Essentially then, those with high expertise who seek information are likely to engage in less of a search than those with low product expertise (Gilly et al, 1998). This was further substantiated by Brucks (1985).

As reported in Gilly et al. (1998), Bloch et al. (1986) determined that those who are assumed to possess a high degree of expertise would typically devote little effort to information search prior to purchase. The researchers suggested that this was so since there was no need to seek additional information because the seekers already possessed 
high product knowledge. Thus, they felt little need to consult others before making product selection. Conversely, "consumers with less product knowledge and experience [expertise] are more likely to doubt their own ability to make good product choices and therefore are likely to feel compelled to ask others for product advice" (p.86).

In their research, Gilly et al. (1998) reported studies which suggest that this relationship does exist. Specifically, Furse et al. (1984, in Gilly et al. 1998) indicated the existence of a negative relationship between information seeking and Receiver's expertise. In their study on car purchasing behaviour, Furse et al. (1984) determined that those who were less experienced were more likely to solicit the advice of others. Conversely, those who were more experienced were not likely to rely on the expertise of others.

Hence, in light of the foregoing explanation, the following hypothesis is theorized:

H7: The greater the Receiver's expertise, the lesser the WOM will be actively sought by the Receiver.

In addition, to the aforementioned likely effect, there is also a likely link between Receiver's expertise and Receiver's perceived risk. Kiel and Layton (1981), based upon their research suggested that, "those with less product experience [expertise] probably perceive more risk and, from an information economics perspective, have the most to gain from engaging in WOM information gathering" (in Gilly et al, 1998, p.86).

Therefore, the following hypothesis is put forth:

H8: The greater the Receiver's expertise, the lesser the Receiver's perceived risk associated with the service. 
It has been suggested that one's expertise is a force that acts to shape the results of persuasion attempts (Friestad and Wright 1994). Further, consumers with prior impressions of a target brand are less affected by WOM than those with little or no previously conceived notions (Herr et al. 1991). Therefore, it can be reasoned that WOM information's influence on the Receiver will likely be low when the Receiver's expertise is high and vice versa.

The following hypothesis is therefore submitted:

H9: The greater the Receiver's level of expertise, the lesser the influence of the Sender's WOM on the Receiver's purchase decision. 


\section{Chapter 4}

\section{RESEARCH DESIGN, METHODOLOGY AND RESULTS}

\section{Methodology}

In previous chapters which have been presented, literature from the areas of marketing, psychology and sociology have been explored resulting in the formulation of the conceptual model in Figure 3. This model proposed that communicative forces are in effect resulting in an impact on the overall influence of the Sender's WOM on the Receiver's purchase decision.

With a view to empirically examining the conceptual model, existing measures needed to be adapted and improved. Items based on contemporaneous scales were used to measure the model's constructs. Most of the scales, however, were designed for products and not services measurement. To address this concern, scales were slightly modified to reflect the requirement for measuring services, largely by substituting the word "products" with "services". Thus, measures were ameliorated and adapted to the needs of this study. In so doing, no significant difficulty was encountered since most products have a services component associated with them. Thus measures were customized to the needs of this study.

This chapter will present the proposed setting for the empirical test of the model and the results of a pretest conducted to develop and refine measures of the various constructs of interest. Additionally, this chapter will also include a brief discussion of the proposed methodology for the main study. Lastly, an analysis and description of salient 
aspects associated with the research design, methodology and attained results will be presented.

\section{Proposed Research Setting and Selection of Reapondents}

In theory falsification contexts, Calder, Phillips and Tybout (1981) suggest that respondents be selected from a sample which is homogeneous in non-theoretical variables. The researchers also mention that the chosen research setting should be one that allows "operationalization" of theoretical constructs and is free from external sources of variation, for example, free of variation of variables not of theoretical interest. It is reasoned that, "extraneous variation can produce spurious effects on the dependent variable and at a minimum, inflate error variance (Cook and Campbell 1995). To the extent that theoretically irrelevant factors are at work, significant relationships between the phenomenon under study may be obscured and the risk of Type II error may be increased. Insulated test settings minimize such irrelevancies" (Calder, Phillips and Tybout 1981, p.202).

This could be achieved by using controlled laboratory settings, however, when research involves variables which are not easily measured under such conditions, field settings are appropriate (Calder, Phillips and Tybout 1981). This is a highly applicable assertion within this context since valid data on WOM processes would be difficult to obtain within a laboratory setting. Hence, a field setting is appropriate.

As indicated by Calder, Phillips and Tybout (1981), early empirical work can be productively pursued on small subsets of the general population and then progressively replicated on more diverse sub-samples over time. 
In order to minimize the effect of extrancous sources of variation, data was collected using survey data from respondents who indicated the acquisition of one service within a 24 month period of completing the questionnaire. This period was deemed appropriate in an effort to also address the concern of using retrospective data.

It was believed that empirical measurement of the proposed conceptual model would be best facilitated by using a questionnaire format in order to attain the required measurement information. Specifically, using retrospective data, respondents would be asked to cast their minds back to a time when they attained information via WOM, regarding a service that they were desirous of purchasing.

The inherent dangers of retrospective data measurement were minimized. Subjects were selected based on the self-admission that they had (newly) arrived in their present home location (ie., within a two-year period). The underlying premise for this was that newly arrived persons would typically be in need of many new services and therefore, would solicit WOM information regarding potential services and respective providers. Thus, it is presumed that the entire WOM situation would be relatively fresh in their minds.

The use of retrospective data was extensively used by Keaveney (1995). In her study of service switching behaviour, she first asked respondents to indicate which of the suggested 25 services they had purchased within the last six months. Respondents were then asked to recall the last time that they switched service providers. Notwithstanding 
the retrospectivity of the questionnaire, problems of retrospective data were minimized since,

The question was carefully worded to echieve several objectives: (1) It allowed respondents to select service switching incidents of their own choosing, without constraining them to specific industries; (2) It asked for the most recent observation to prevent respondents from describing only the more dramatic or vivid incidents. The most recent cbservation should be well remembered; and (3) Finally, the question gave respondents time to collect their thoughts and to have incidents clearly in mind (Keaveney 1995, p.73).

This thesis research generally meets the aforementioned objectives that Keaveny (1995) described. Initially, within the questionnaire, respondents were asked to select a service in which WOM information was attained. It was stressed that the service is one on which information from another person was attained prior to purchasing the service. In order to focus respondents, a list of suggested services was provided. This also served to illustrate to respondents exactly what services are, as opposed to products.

Starting from the beginning of the questionnaire, and throughout, respondents were reminded to use the initially identified service as a basis for all answers. By deliberately building redundancy into the questionnaire, respondents were reminded of this in each section of the questionnaire. Thus, reasonable assurance was attained that all answers were related to the same situation.

A questionnaire survey was used to collect the required information and data in order to test the hypotheses. The target participants were newly posted military members and their dependants at Canadian Forces Base Gagetown, New Brunswick. Since the military community is extremely transitory, with members moving on average every two to three years, dependents must seek new service providers with each posting. This is 
especially applicable to dependents where upon arrival at a new base, services such as medical, dental, child care, hairstylist, in addition to many others must be attained. The military community lends itself well to empirical research since it is relatively homogeneous in terms of demographic and lifestyle characteristics. Additionally, it is believed that WOM forms the primary means of attaining information on services.

The main issue is, therefore, how they became aware of these service providers. It is highly likely that WOM is the most common means of attaining the required information. This notion was supported by Bristor (1990) who indicated that, in an effort to save time, "a person moving to a new town may have extensive information needs and may gather it most efficiently by asking people "where to go for...." or "what is the best....." In the extreme, a shortage of time may also lead to the use of word of mouth as a substitute for external search or active decision making" (p.57).

Substantiating the claim that new arrivals within a community rely on WOM in order to acquire information, Feldman and Spencer (1965) indicated that approximately 65 percent of new residents in a community relied on WOM to select a physician.

\section{THE SURVEY QUESTIONNAIRE}

Ultimately, the aim in conducting the measurements was to measure the relationships between constructs within the proposed model. In order to facilitate this, individual items were measured. Scales used to measure most of the constructs were adapted from pre-existing scales and as mentioned, adaption primarily consisted of amending the terminology to reflect services as opposed to products.

As seen at Appendix A, the questionnaire consisted of 10 sections: Sections A to 
J. Section A indicated the date on which the questionnaire was completed, as well as the date that the subject arrived at his/her present location (home). This facilitated a determination of the time lapse between arrival and completion of the questionnaire. As mentioned, a cut-off time lapse of 24 months was used.

Section B asked the respondent to select a service on which to base all subsequent responses.

Sections $\mathbf{C}$ through $\mathrm{H}$ measured constructs in the proposed model. Items in Section $C$ measured tie strength; Section $D$ and $E$ items measured perceived expertise of the Sender and Receiver, respectively; Section F items measured risk; Section G measured how actively WOM was sought; and Section $\mathbf{H}$ measured the ultimate dependent variable, the influence of WOM on purchase decision. Items in Section I measured involvement, which was not part of this study, however, data was collected for future research.

Lastly, demographic information was collected within Section J of the questionnaire.

In order to measure constructs within the conceptual model, existing scales were used for all constructs with the exception of one. The constructs of tie strength, Sender's expertise, Receiver's expertise, Receiver's perceived risk and the ultimate dependent variable, the influence of the Sender's WOM in the Receiver's purchase decision, were measured using scales which were adapted from existing scales. The one and only new scale used within this study measured the construct of how actively WOM was sought by the Receiver. 


\section{Scales}

It is believed that the following scales capture the items in a most efficient, reliable and valid manner. The derivation of each will be described.

Tie Strength. The construct of tie strength was measured using an adapted scale from Frenzen and Davis (1990). In their study, the researchers investigated the concept of market embeddedness and its impact on purchasing behaviour in a consumer market. They measured the strength of the buyer-seller tie in an effort to determine the effect of this tie on likelihood of purchase. They gathered data for four indicators of tie strength: closeness, intimacy, support and association. For closeness, they used a ten-point scale, where 10 was "extraordinary" and 1 was "not close at all". The remaining indicators 'were based on respondents' reported likelihood of engaging in various activities with a respondent" (p.6). A six-point scale was used with responses ranging from 5 meaning "very likely" to 0 meaning "I don't know this person". The researchers then summed the four indicators to form a 25 point composite tie strength measure.

This thesis uses the same interpretations for the items that Frenzen and Davis (1990) used for their study. Closeness was interpreted as the respondents' reported relationship to the target individual. Intimacy was measured as, "the likelihood of sharing a personal confidence with a target individual" (p.6). Support was measured as, "a respondent's reported likelihood of extending everyday (as opposed to emergency) assistance to a target individual" (p.6). Association "was measured by a respondent's professed likelihood of spending a free afternoon with a target individual" (p.6). 
The researchers reported reliability estimates as being most acceptable.

Cronbach's Alpha for the tie strength composite was reported to be 0.93 for both the pre and post-party samples. They also stated that the test-retest correlation coefficient was 0.91 after a three-week interval between pre and post-party observations.

Within the questionnaire used in this thesis, Section C consists of the tie strength measure. Slight modifications were made to Frenzen and Davis' (1990) scales in order to adapt it to a WOM scenario within a services context. All items were formulated using a seven point scale. Closeness was measured at item $\mathrm{Cl}$ on the questionnaire, using the anchors of " 1 = not close at all" and " 7 = extraordinarily close". The anchors of intimacy, support and association were measured at C2, C3 and C4, respectively, in the questionnaire and were anchored as, " 1 = very unlikely" and " $7=$ very likely".

Sender's Expertise. The construct of Sender's expertise was measured using scales adopted from Netemeyer and Bearden (1992). These researchers conducted an investigation into the effects of experimental manipulations of constructs within two models of reasoned action used to predict behavioural intentions toward marketing- and consumer-related behaviours. The expertise scale was used to provide evidence that successful manipulation had occurred.

The researchers used a five-item, seven point semantic differential to measure a consumer's assessment of a specified person's knowledge and competency as a source of information about a particular product. Reliability of the scales was reported as being very good with alphas of 0.94 and 0.91 for the two models of behavioural intention that were tested. 
The items used by these-researchers were casily adapted to a WOM scenario within a services purchase context. The anchors of thowledgeable, competent, expert, trained and experienced as related to the Receiver's perceptions about the Sender, are indicated within Section D of the questionnaire at items D1a, D1b, D1c, D1d and D1e. Under this section, respondents are asked to relate their opinions to the request to rate the Sender in terms of each of the items. Again, as in the originally designed scale, a sevenpoint scale was used.

Receiver's Expertise. The construct of Receiver's expertise was measured using an adapted scale form Mishra, Umesh and Stem (1993). In their study, the researchers investigated the attraction effect within a context of product purchase selection. In their model, the construct of expertise was measured using a four-item, seven point semantic differential scale designed to measure the degree of knowledge and experience that a subject reported to have had about a specific product class. For all three product classes, the researchers reported alphas of 0.90 .

Section $\mathbf{E}$ of the questionnaire seeked to measure the construct of Receiver's expertise. In order to orient the scale to services requirements, slight modification was required where the initial question asked participants to rate their own expertise regarding their selected service at the time of receipt of the WOM message. The same items as used in the source study was used in the questionnaire. Using the seven-point scale, anchors used were: knew very little/much about it, inexperienced/experienced, uninformed/informed and novice/expert buyer at items E1a, E1b, E1c and E1d, respectively. 


\section{Receiver's Perceived Risk. The construct of Receiver's perceived risk was} measured using an adapted scale from Murray and Schlacter (1990). The researchers examined differences in perceived risk and variability between goods and services. In their study the researchers constructed six fixed interval scales, each with seven points anchored by low loss to high loss. Overall perceived risk scores were summed across each of the six loss dimensions for each respondent as a function of each product type which was rated. As indicated in the study, questions were oriented towards the components of financial, performance, physical, psychological, social and convenience loss. All of the scales were designed for services applications. The overall mean of 0.877 was reported as the internal consistency (alpha) of perceived risk. This was deemed as being acceptable for use in this thesis.

Actual questions used for each dimension were not indicated within the Murray and Schlacter (1990) study although, as the authors mentioned, they used the stated hypotheses as a basis for question formulation. Therefore, questions for the thesis questionnaire were likewise formulated using the stated hypotheses in the Murray and Schlacter (1990) study as a basis.

Section $\mathbf{F}$ in the thesis questionnaire, captured the measurement of the perceived risk construct. Seven items, each with a seven-point scale were used. Each was anchored by not risky at all and extremely risky. The questionnaire dimensions of financial, performance, physical, psychological, social, convenience, and overall risk were indicated at items F1, F2, F3, F4, F5, F6 and F7, respectively.

WOM Actively Sought by Receiver. As was previously mentioned, a unique 
characteristic of this thesis is the measurement of how actively the Receiver sought WOM information. As a result of this unique characteristic, there is no measure of this construct in the literature. Indeed, no known previous researchers have pursued an examination of this construct. Hence, no established scale exists. In an effort to measure this construct, two questions were developed.

The construct was measured in Section $\mathbf{G}$ of the questionnaire by simply asking the participant to indicate the degree to which he/she agreed with two statements at G1 and G2. The first statement related to the receiver explicitly requesting information from the Sender of the WOM message. The second statement reflected the number of attempts that the Receiver made while trying to gather information from the Sender of the WOM message. It was believed that making numerous attempts to gather information is indicative of an active search for information.

Influence of Sender's WOM on the Receiver's Purchase Deeision. The ultimate dependent variable is the Influence of Sender's WOM on the Receiver's Purchase Decision. The Gilley et al. (1998) study provided scales for measurement of this construct. In their study, the researchers examined WOM within a dyadic framework where perceptions of both the information seeker and the source were obtained. Furthermore, they investigated WOM, within a product purchase scenario, by examining several constructs which comprised a proposed conceptual model.

Gilley et al. (1998) used a ten item influence measure in their study. When the source of the WOM information reported his/her perceptions, Cronbach's alpha score was 0.90 and when the seeker rated his/her perceptions, it was 0.88 . 
The aforementioned measure was modified for this thesis. Instead of using the entire ten items of the measure, eight were used; two were deleted for reasons of applicability. It was believed that the last two items, in light of the fact that the thesis is using retrospective data, did not apply to the services context which was being examined within the thesis. In the Gilly study, the question was asked if the person would have any influence on the product/service and how much influence the person would have on the brand/provider of the product/service that was purchased.

In the thesis questionnaire, Section $\mathbf{H}$ measured this construct by using eight items per the Gilley et al. (1998) study. A seven point scale anchored by strongly disagree and strongly agree was used. Items H1, H2, H3, H4, H5, H6, H7 and $\mathrm{H8}$ measured items related to this construct.

Involvement. As seen in the questionnaire, the construct of involvement was measured. This was included for the aim of gathering data for possible related research for future use. Hence, this construct will not be further discussed.

\section{PRETEST STUDY}

Prior to administering the questionnaire in the main study, a pilot study was conducted, the aim of which was to test and validate scales. The questionnaire is presented as Appendix $\mathbf{A}$.

A pre-test was conducted on 29 October 1998 at the University of New Brunswick. Subjects were second and third year undergraduates in three business classes. No incentives were offered to the subjects in retum for their participation. Hence, 
subjects' participation was completely voluntary.

Of the 88 questionnaires that were distributed, 6 were discarded because they were not entirely completed (entire sections were omitted). Therefore, the total number of usable questionnaires was 82.

\section{Psychometric Properties of the Pretest Seales}

As previously indicated, all but one of the scales were extensively tested and documented in the literature. These scales were found to be reliable in earlier studies. Reliability analysis for the employed scales were indicated in the aforementioned description under the sub-heading of "Scales." The reliability of all the scales were adequate since they fully met Nunnally's (1978) standard (alphas should be greater than 0.7 .

Statistical analysis was completed upon the pretest results. Initially, SPSS was used in order to primarily calculate reliability analysis (Cronbach's alphas: reliability coefficients) in addition to basic statistical trends.

Internal consistency of the measure was attained by Cronbach's alpha. A summary of key statistical results as calculated by SPSS is as follows:

\begin{tabular}{|c|c|c|c|c|c|}
\hline Coastruet & Iten & $\underset{\text { Dexeriotion }}{\text { Item }}$ & Mean & Standand & Alphan \\
\hline \multirow[b]{3}{*}{ Tie Strength } & Cl & $\begin{array}{l}\text { Relationship with } \\
\text { Sender }\end{array}$ & 5.0244 & 1.4052 & \multirow[b]{3}{*}{0.8982} \\
\hline & C2 & $\begin{array}{l}\text { Likelihood of sharing a } \\
\text { personal confidence }\end{array}$ & 4.9634 & 1.5748 & \\
\hline & C3 & $\begin{array}{l}\text { Likelihood of extending } \\
\text { a everyday essistance }\end{array}$ & 4.8537 & 1.7006 & \\
\hline
\end{tabular}




\begin{tabular}{|c|c|c|c|c|c|}
\hline Construet & Iten & 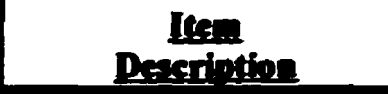 & Men & Sindend & Alohe \\
\hline & $\mathrm{CA}$ & $\begin{array}{l}\text { Likelihood of spending } \\
\text { free time together }\end{array}$ & 4.6585 & 2.0561 & \\
\hline \multirow{5}{*}{$\begin{array}{l}\text { Expertise of } \\
\text { Sender }\end{array}$} & Dla & Knowledgeable & 5.2073 & 1.0273 & \multirow{5}{*}{0.8640} \\
\hline & D1b & Competent & 5.1707 & 1.0281 & \\
\hline & Dlc & Expert & 3.9146 & 1.3536 & \\
\hline & D1d & Trained & 3.3780 & 1.5287 & \\
\hline & Dle & Experienced & 4.7927 & 1.5455 & \\
\hline \multirow{4}{*}{$\begin{array}{l}\text { Expertise of } \\
\text { Receiver }\end{array}$} & Ela & Knowledge & 3.9756 & 1.4739 & \multirow{4}{*}{0.8625} \\
\hline & Elb & Experience & 3.9878 & 1.4358 & \\
\hline & Elc & Informed & 4.0122 & 1.3743 & \\
\hline & Eld & Novice/Expent & 4.0732 & 1.4123 & \\
\hline \multirow{7}{*}{ Risk } & $\mathbf{F 1}$ & Finencial & 2.5976 & 1.5702 & \multirow{7}{*}{0.8352} \\
\hline & $\mathbf{F 2}$ & Performance & 3.3659 & 1.5910 & \\
\hline & F3 & Convenience & 2.9512 & 1.5146 & \\
\hline & $\mathbf{F 4}$ & Physical harm & 1.9878 & 1.5194 & \\
\hline & F5 & Psychological harm & 2.4634 & 1.8203 & \\
\hline & F6 & Social harm & 1.9268 & 1.5458 & \\
\hline & F7 & Overall risk & 2.5000 & 1.4928 & \\
\hline \multirow{2}{*}{$\begin{array}{l}\text { WOM } \\
\text { actively } \\
\text { sought }\end{array}$} & Gl & Explicit request & 4.1481 & 1.9047 & \multirow{2}{*}{0.8416} \\
\hline & $\mathbf{G} 2$ & $\begin{array}{l}\text { Number of attempts } \\
\text { made }\end{array}$ & 3.4568 & 1.9108 & \\
\hline \multirow{5}{*}{$\begin{array}{l}\text { Influence of } \\
\text { Sender's } \\
\text { WOM }\end{array}$} & $\begin{array}{l}\text { Hl (neg } \\
\text { coded) }\end{array}$ & Little new info given & 4.6585 & 1.2979 & \multirow{5}{*}{0.8107} \\
\hline & $\mathrm{H} 2$ & Significant influence & 4.8902 & 1.3878 & \\
\hline & $\mathbf{H 3}$ & $\begin{array}{l}\text { Mention of helpful } \\
\text { things }\end{array}$ & 5.1463 & 1.2583 & \\
\hline & H4 & Provided different ideas & 4.3415 & 1.4675 & \\
\hline & $\begin{array}{l}\text { HS (neg } \\
\text { coded) }\end{array}$ & Mind was not changed & 4.7927 & 1.3943 & \\
\hline
\end{tabular}




\begin{tabular}{|c|c|c|c|c|c|}
\hline Construet & Iten & Dexeriotion & Mene & $\begin{array}{l}\text { Siandard } \\
\text { Denintion }\end{array}$ & Alphe \\
\hline & H6 & Really helped & 5.1098 & 1.2571 & \\
\hline & H7 & Influence in service & 4.7683 & 1.3361 & \\
\hline & H8 & Influence on features & 4.2195 & 1.5318 & \\
\hline
\end{tabular}

Table 1. Summary of pre-test preliminary statistical analysis.

\section{Conclusions From Pretest}

Based on the foregoing, in light of the high reliabilities (all alpha values exceed 0.70), no amendments were made to the questionnaire. Hence, the questionnaire, in its originally configured form was used for the main study.

\section{MAIN STUDY}

On 12 November 1998, the questionnaires were distributed to all units located at Canadian Forces Base Gagetown, New Brunswick. By 17 December 1998, all questionnaires which had been completed were returned and preliminary statistical review was initiated. No discernment among the respondents was made on the basis of rank, experience, position, etc. Participation was completely voluntary and responses were strictly confidential.

The total number of survey questionnaires which were distributed was 450 . Returned, were 176 forms, of which 165 were tisable. Discarded, were 11 forms, for two main reasons: (1) lack of completion (major sections not completed); and (2) obvious misunderstanding as evidenced by respondents' indicating either product purchase vice the required service purchase, or numerous service choices instead of only one. 
In an effort to reduce the impact of problems associated with retrospective data, a cut-off point of 24 months between arrival at the new geographic location of residence and completing the questionnaire was used. Hence, the remaining 113 questionnaires were used as the data set for statistical analysis.

\section{Demographics of Data Set}

Of the 113 questionnaire that were used, 80.5 percent were male and 19.5 percent were female. Respondents were aged from 21 to 53 years old with the mean being 35.6 years and 40 years being the highest frequency.

Reported education levels were as follows:

\begin{tabular}{|c|c|c|}
\hline Bitheat Attrined Ednontion & Preoneney & Percent \\
\hline Did not complete high sehool & 13 & 11.5 \\
\hline High school graduate & 55 & 48.7 \\
\hline $\begin{array}{l}\text { Techuical or community colleze } \\
\text { graduate }\end{array}$ & 21 & 18.6 \\
\hline Undergradunte university degree & 19 & 16.8 \\
\hline Post-graduate degree & 4 & 3.5 \\
\hline Missing & 1 & 0.9 \\
\hline
\end{tabular}

Table 2. Respondents' education levels. 
The respondents' personal income brackets were as follows:

\begin{tabular}{|l|c|c|}
\hline \multicolumn{1}{|c|}{ Income Brocket } & Erequency & Persent \\
\hline Less than 520,000 & 7 & 6.2 \\
\hline $520,000-\$ 39,999$ & 42 & 37.2 \\
\hline $540,000-559,999$ & 50 & 44.2 \\
\hline $560,000-580,000$ & 10 & 8.8 \\
\hline Above $\$ 80,000$ & 0 & 0 \\
\hline Missing & 4 & 3.5 \\
\hline
\end{tabular}

Table 3. Respondents' personal income brackets.

Household income brackets were as follows:

\begin{tabular}{|l|c|c|}
\hline \multicolumn{1}{|c|}{ Income Bracket } & Frequeney & Percent \\
\hline Less than 520,000 & 4 & 3.5 \\
\hline $520,000-\$ 39,999$ & 27 & 23.9 \\
\hline $540,000-\$ 59,999$ & 43 & 38.1 \\
\hline $560,000-\$ 80,000$ & 20 & 17.7 \\
\hline S80,000 - 599,999 & 11 & 9.7 \\
\hline Above $\$ 100,000$ & 4 & 3.5 \\
\hline Missing & 4 & 3.5 \\
\hline
\end{tabular}

Table 4. Respondents' household income levels.

\section{Measurement Model}

A three-stage analytical process was applied to the measurement model. Firstly, exploratory factor analysis (principal component analysis and reliability analysis) using SPSS 8.0 for Windows was completed in order to refine scales. Secondly, scales which were obtained (and items which were retained) as a result of the first stage analysis were subjected to confirmatory factor analysis. This was completed using LISREL8 to assess 
convergent validity, error variance and internal consistency. Thirdly, path analysis was used to estimate the causal paths of the model.

\section{Stage 1 - Exploratory Analysis}

All 30 items measuring six constructs from the pretest were retained for this (initial) stage of the analysis. Preliminary psychometric analysis was performed on the scales using SPSS for Windows. A summary of the results is contained in Table 5 below.

Tie Strength. For the tie strength scale, an alpha of 0.8657 was obtained. Items $\mathrm{C1}, \mathrm{C2}, \mathrm{C3}$ and $\mathrm{C4}$ were the relevant measures. Since the deletion of any of the items would not enhance the reliability (that is, increase the alpha), all items were retained for stage two of the analysis.

Sender's Expertise. For the Sender's Expertise scale, an alpha of 0.9132 was attained. Items D1a, D1b, D1c, D1d and D1e were the relevant measures. Since the deletion of any of the items would not enhance the reliability (that is, increase the alpha), all items were retained for stage two of the analysis.

Receiver's Expertise. For the scale Receiver's Expertise, an alpha of 0.9298 was obtained. Items E1a, E1b, Elc and E1d were relevant measures. Although deleting Item Eld would have raised the Alpha to 0.9360 , it was decided, in light of the relatively small increase, to allow this item to remain for the subsequent confirmatory internal reliability analysis in stage two (using LISREL). Therefore, all items for the scale were retained for stage two of the analysis. 
Risk. For the Receiver's Perceived Risk scale, an alpha of 0.6903 was attained. Items F1, F2, F3, F4, F5 and F6. Item F7, which was included in the battery of items for this construct, was not included in the analysis since it measured overall perceived risk. Overall risk was deemed to be an all-encompassing item which essentially served to measure, in an inclusive fashion, all elements of the previous items.

Additionally, factor analysis for six items was conducted on this construct; two factors resulted. Items F1, F2 and F3 loaded heavily on one factor. Item F4 loaded lightly and evenly on both factors. Items F5 and F6 loaded heavily on the second factor. Considering this loading configuration, no meaningful interpretation of factors could be attained. In light of these results, and also considering the relatively low alpha of 0.6903 , it was decided to retain item F7 and use it as a separate factor unto itself. Hence, item F7, overall perceived risk, was used as the sole item for measuring the construct of risk in subsequent stages of the analysis.

WOM Actively Sought. For the WOM Actively Sought by Receiver scale, an alpha of 0.6348 was attained. Items G1 and G2 were the relevant measures. This low measure of reliability for the scale was likely due to several reasons. The scale which was used, was not one which was previously developed and tested in other studies. The twoitem scale was formulated based on intuitive reasoning and therefore the question of how explicitly the Receiver requested the WOM information from the Sender was asked in item G1. Additionally, in item G2, the Receiver was asked to indicate whether he/she had made numerous attempts to gather the information from the Sender. 
In light of the aforementioned concerns, it was decided that the second item, G2, should be deleted from subsequent analytical consideration. This decision was based on the premise that the frequency of attempts, taken alone, might not be a true measure of how actively WOM information is sought. In order for this item to be accepted, it was believed that additional items indicating how actively sought the WOM information is would have to be included. Thus, the one remaining item, G1, was retained for subsequent analysis.

Influence of Sender's WOM. For the Influence of Sender's WOM on the Receiver's Purchase Decision scale, and alpha of 0.7626 was attained. Eight items, HI through H8, were used to measure the construct. Items $\mathrm{H1}$ and $\mathrm{HS}$ were reverse coded for the analysis since the questions were negatively worded. By deleting item H1 from analysis, the reliability measure could be increased to 0.7992 . Moreover, deleting item H5 could increase the alpha to 0.7787 . The lack of reliability could be due to directionality of wording. Since negatively worded items may produce confounding results in long questionnaires (Carman 1990), items H1 and HS were deleted. Therefore, items $\mathrm{H2}, \mathrm{H3}, \mathrm{H4}, \mathrm{H6}, \mathrm{H7}$ and $\mathrm{H8}$ were retained for stage two of the analysis.

The foregoing discussion regarding reliability analysis, in addition to some salient statistical measures, is summarized in the following table. It should be noted that the indicated reliability measures are the initially attained ones and not the-improved alphas which could be attained by deleting specific items. 


\begin{tabular}{|c|c|c|c|c|c|}
\hline Constrnet & Iten & Decrion & Ian & Syndent & Alnth \\
\hline \multirow{4}{*}{ Tie Strength } & $\mathrm{Cl}$ & $\begin{array}{l}\text { Relntionship with } \\
\text { Seader }\end{array}$ & 3.7080 & 1.4801 & \multirow{4}{*}{0.8657} \\
\hline & $C 2$ & $\begin{array}{l}\text { Likelihood of } \\
\text { sharing a personal } \\
\text { confidence }\end{array}$ & 3.1947 & 1.7871 & \\
\hline & C3 & $\begin{array}{l}\text { Likelihood of } \\
\text { extending a } \\
\text { everyday } \\
\text { assistence }\end{array}$ & 4.0619 & 1.7941 & \\
\hline & $\mathrm{CA}$ & $\begin{array}{l}\text { Likelihood of } \\
\text { spending free time } \\
\text { together }\end{array}$ & 3.3274 & 1.9569 & \\
\hline \multirow{5}{*}{$\begin{array}{l}\text { Sender's } \\
\text { Expertise }\end{array}$} & Dla & Knowledgeable & 4.9115 & 1.4611 & \multirow{5}{*}{0.9132} \\
\hline & Dlb & Competent & 4.7514 & 1.5441 & \\
\hline & Dle & Expext & 4.0897 & 1.6122 & \\
\hline & Dld & Trained & 3.5990 & 1.8198 & \\
\hline & Dle & Experienced & 4.4690 & 1.7932 & \\
\hline \multirow{4}{*}{$\begin{array}{l}\text { Recelver's } \\
\text { Expertise }\end{array}$} & Ele & Knowledge & 3.9381 & 1.6865 & \multirow{4}{*}{0.9298} \\
\hline & Elb & Experience & 3.7699 & 1.6956 & \\
\hline & Elc & Informed & 3.9115 & 1.5786 & \\
\hline & Eld & Novice/Expent & 3.8853 & 1.6022 & \\
\hline \multirow{6}{*}{ Risk } & F1 & Finencial & 2.6549 & 1.5855 & \multirow{6}{*}{0.6903} \\
\hline & $\mathbf{F} 2$ & Performance & 3.3274 & 1.5552 & \\
\hline & F3 & Convenience & 2.8053 & 1.4569 & \\
\hline & F4 & Physical harm & 2.0973 & 1.5866 & \\
\hline & F5 & $\begin{array}{l}\text { Psychological } \\
\text { harm }\end{array}$ & 1.9027 & 1.3691 & \\
\hline & F6 & Social harm & 1.5575 & 1.1255 & \\
\hline \multirow{2}{*}{$\begin{array}{l}\text { WOM } \\
\text { actively } \\
\text { sought }\end{array}$} & $\mathbf{G l}$ & Explicit request & 4.3009 & 1.9995 & \multirow{2}{*}{0.6348} \\
\hline & $\mathbf{G 2}$ & $\begin{array}{l}\text { Number of } \\
\text { attempts made }\end{array}$ & 3.0088 & 1.8492 & \\
\hline
\end{tabular}




\begin{tabular}{|c|c|c|c|c|c|}
\hline Conatint & Itan & $\tan$ & Men & Standax & Anth \\
\hline \multirow{8}{*}{$\begin{array}{l}\text { Influence of } \\
\text { Sender's } \\
\text { WOM }\end{array}$} & $\begin{array}{l}\text { Hl (nes } \\
\text { coded) }\end{array}$ & $\begin{array}{l}\text { Litule new info } \\
\text { given }\end{array}$ & 4.7611 & 1.5995 & \multirow{8}{*}{0.7626} \\
\hline & $\mathbf{H 2}$ & $\begin{array}{l}\text { Significant } \\
\text { influence }\end{array}$ & 4.4867 & 1.7326 & \\
\hline & $\mathbf{H 3}$ & $\begin{array}{l}\text { Mention of helpful } \\
\text { things }\end{array}$ & 5.0354 & 1.4450 & \\
\hline & H4 & $\begin{array}{l}\text { Provided different } \\
\text { ideas }\end{array}$ & 3.9027 & 1.7473 & \\
\hline & $\begin{array}{l}\text { H5 (neg } \\
\text { coded) }\end{array}$ & $\begin{array}{l}\text { Mind was not } \\
\text { changed }\end{array}$ & 4.3491 & 1.7357 & \\
\hline & 46 & Really helped & 4.5909 & 1.8006 & \\
\hline & H7 & $\begin{array}{l}\text { Influence in } \\
\text { service }\end{array}$ & 4.3186 & 1.8335 & \\
\hline & H8 & $\begin{array}{l}\text { Influence on } \\
\text { fentures }\end{array}$ & 3.7788 & 1.8358 & \\
\hline
\end{tabular}

Table 5. A summary of salient measure attained from Stage 1 analysis.

\section{Stage 2 - Confirmatory Analysis: Internal Consistency of the Seales}

Confirmatory factor analysis was performed on the scales involving the measures that were retained for analysis after exploratory examination in Section 1. The confirmatory factor analysis was conducted using LISRE8 (Joreskog and Sorbom 1993). For the assessment of the model, multiple fit indices are reported. The traditional $\chi^{2}$ is reported. Five additional fit indices are also reported: $\chi^{2} / \mathrm{df}$ (Chi-square/Degrees of Freedom) (Wheaton et al. 1977); AGFI (Adjusted Goodness of Fit Index) (Joreskog and Sorbom 1993); RNI' (Relative Non-Centrality Index) (McDonald and Marsh 1990);

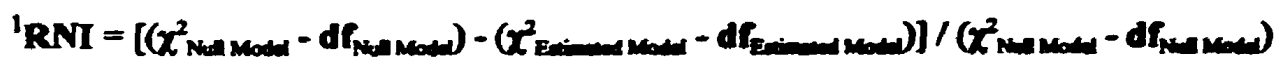


RMSEA (Root Mean Square Error of Approximation) (Steiger 1990); and CFI (Comparative Fit Index) (Bentler 1990).

Acceptable model fits are indicated by the values of $\chi^{2} / \mathrm{df}$ below 5.00, AGFI exceeding 0.80 (Taylor and Todd 1995), RNI values exceeding 0.90 (Marsh 1994), CFI values exceeding 0.90 , and the RMSEA values below 0.10 with values less than 0.80 suggesting an adequate fit (Browne and Cudeck 1993). Standardized data was used for all subsequent analysis. Standardization of data is desirable when several variables are being used in an analysis because the measures may be sensitive to differing scales (although all scales were 7-point within the study). The process of standardization "eliminates the bias introduced by the difference in the scales of the several attributes of variables used on the analysis" (Hair et al. 1995, p.435).

Overall, the fit indices indicate that the model was reasonably consistent with the data, with all the fit indices close to, or better than, the recommended values $\left[x^{2}=296.39\right.$ $(p>0.05), \mathrm{df}=146, \chi^{2} / \mathrm{df}=2.03, \mathrm{AGFI}=0.73, \mathrm{RNI}=0.89, \mathrm{CFI}=0.89$, and $\mathrm{RMSEA}=$ 0.096]. The model accounts for $34 \%$ of the variance in the dependent variable.

To further assess the validity of the measures, Bollen (1989) suggested a scrutiny of factor loadings as well as the squared multiple correlations between the items and the constructs. Factor loadings $(\lambda)$ of 0.60 are generally considered the minimal level at which convergent validity could be suggested (Bagozzi and Yi 1988). For the squared multiple correlations $\left(R^{2}\right)$, values above 0.40 are suggestive of a substantial shared 
variance with their hypothesised constructs (Taylor and Todd 1995). In addition to assessing validity of the measures, internal consistency measures (Fornell and Larkker 1981) were calculated for each scale/construct with loadings obtained from the confirmatory factor analysis.

Internal consistency was calculated using the following:

Internal Consistency $=\left(\Sigma \lambda_{\gamma_{i}}\right)^{2} /\left[\left(\Sigma \lambda_{\gamma_{i}}\right)^{2}+\Sigma \operatorname{Var}\left(\varepsilon_{i}\right)\right], \quad$ where $\operatorname{Var}\left(\varepsilon_{i}\right)=1-\lambda_{\lambda_{i}}{ }^{2}$

Table 6 below provides a summary of the factor loadings and the squared multiple correlations for individual items, together with the internal consistency measures for each construct.

\begin{tabular}{|c|c|c|c|c|}
\hline Constrinet & $\begin{array}{l}\text { Internal } \\
\text { Consistengy }\end{array}$ & Item & $\frac{\text { Fantor londing }}{\text { (a) }}$ & $\begin{array}{l}\text { Sanond Mnltiphe } \\
\left.\text { Cornthtions } R^{2}\right)\end{array}$ \\
\hline \multirow{4}{*}{ Tie Strength } & \multirow{4}{*}{0.87} & $\mathrm{Cl}$ & 0.71 & 0.53 \\
\hline & & C2 & 0.75 & 0.61 \\
\hline & & $\mathrm{C}_{3}$ & 0.74 & 0.55 \\
\hline & & C4 & 0.89 & 0.80 \\
\hline \multirow{5}{*}{ Sender's Expertise } & \multirow{5}{*}{0.91} & Dla & 0.90 & 0.74 \\
\hline & & Dlb & 0.93 & 0.78 \\
\hline & & Dle & 0.91 & 0.75 \\
\hline & & Dld & 0.74 & 0.52 \\
\hline & & Dle & 0.82 & 0.59 \\
\hline \multirow{4}{*}{$\begin{array}{l}\text { Receiver's } \\
\text { Expertise }\end{array}$} & \multirow{4}{*}{0.93} & Ela & 0.93 & 0.86 \\
\hline & & Elb & 0.94 & 0.86 \\
\hline & & Elc & 0.87 & 0.78 \\
\hline & & Eld & 0.81 & 0.61 \\
\hline
\end{tabular}




\begin{tabular}{|c|c|c|c|c|}
\hline Constrinet & $\begin{array}{l}\text { Intand } \\
\text { Censintinex }\end{array}$ & Itmen & $\frac{\text { Patorlandlus }}{(\mathrm{n})}$ & 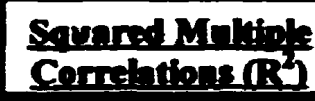 \\
\hline Risk & $\mathbf{N} / \mathbf{A}$ & F7 & \multicolumn{2}{|l|}{ Single item measure } \\
\hline $\begin{array}{l}\text { WOM activety } \\
\text { sought }\end{array}$ & $\mathbf{N} / \mathbf{A}$ & GI & \multicolumn{2}{|l|}{ Single item measure } \\
\hline \multirow{6}{*}{ Influeace of WOM } & \multirow{6}{*}{0.85} & H2 & 0.78 & 0.63 \\
\hline & & $\mathbf{H 3}$ & 0.86 & 0.68 \\
\hline & & H4* & 023 & 0.052 \\
\hline & & H6 & 0.92 & 0.78 \\
\hline & & H7 & 0.72 & 0.52 \\
\hline & & H8* & 0.58 & 0.35 \\
\hline
\end{tabular}

Table 6. A summary of salient features of Stage 2 analysis. Items below the accepted minimum levels are indicated by an asterisk (*).

As mentioned, items with factor loadings of 0.60 and squared multiple correlations of 0.40 are considered the minimum acceptable values and those items which have lower values than these are likely candidates for deletion.

All measures with the exception of items H4 and H8 for the Influence of WOM scale (as indicated by ${ }^{\bullet}$ in Table 6 above), exhibited substantive convergent validity with their respective constructs. Since items $\mathrm{H} 4$ and $\mathbf{H} 8$ did not meet the minimal criteria for the convergent validity based on its factor loadings and the squared multiple correlation, they were deleted from the Influence of WOM scale for Stage 3 of the analysis. Results from Table 6 are also conclusive of scales/constructs that are adequately internally consistent. Table 5, above, contains the descriptive statistics mean and standard deviation for the summated scales. 
Stage 3 - Path Analysis

Struetural Models

Hypothesized paths in each model were tested using LISREL8 (Joreskog and Sorbom 1993) with maximum likelihood (ML) estimation. For the model, overall fit, predictive power and the significance of the paths were considered. $\mathbf{R}^{2}$ for each dependent construct was examined to assess explanatory power, and the significance of individual paths was assessed. In conducting the analysis, all hypothesized paths were estimated. 
The following diagram (Figure 4) indicates the path loadings in addition to t-values for each path.

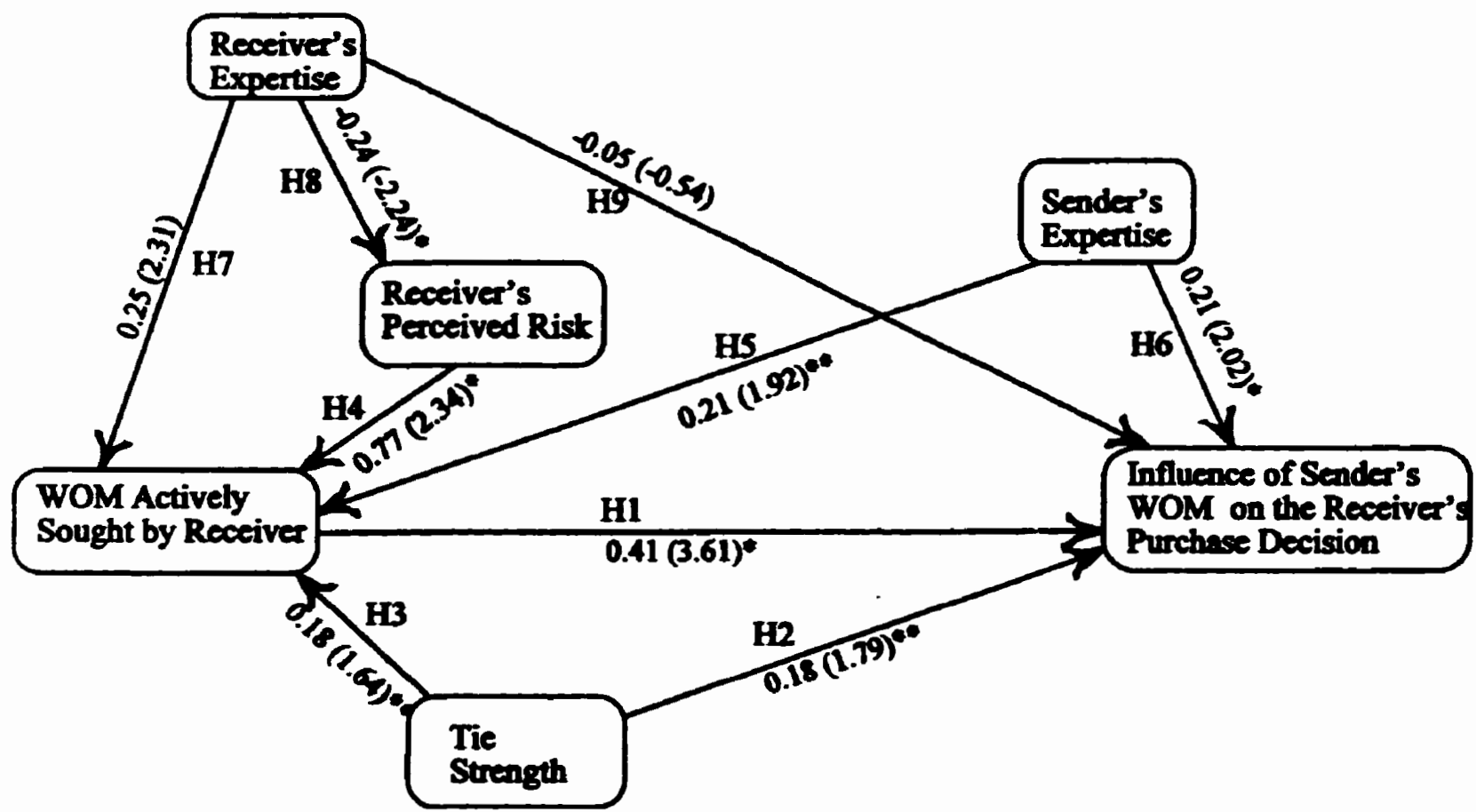

Figure 4. Results of path analysis indicating path loading and t-values. One asterisk (*) denotes significance at the 0.05 level, and two asterisks $\left({ }^{* *}\right)$ denotes significance at the 0.10 level. $T$-values are in parenthesis. 
Summary of Results

\begin{tabular}{|c|c|c|}
\hline Bypothen & Deactition: & Yoltinten Rents \\
\hline $\mathbf{H 1}$ & $\begin{array}{l}\text { The greater the extent to which the WOM is setively } \\
\text { sought by the Receiver, the greater the influence of the } \\
\text { Sender's WOM on the Receiver's purchase decision. }\end{array}$ & $\begin{array}{l}\text { Supported at the } 95 \% \text { level } \\
\text { of confidence }(\alpha=0.05) \text {. }\end{array}$ \\
\hline H2 & $\begin{array}{l}\text { The greater the strength of the tie between the Sender } \\
\text { and the Receiver, the greater the influence of the } \\
\text { Sender's WOM on the Receiver's purchase decision. }\end{array}$ & $\begin{array}{l}\text { Supported at the } 90 \% \text { level } \\
\text { of confidence }(\alpha=0.10) \text {. }\end{array}$ \\
\hline $\mathbf{H 3}$ & $\begin{array}{l}\text { The greater the strength of the tie between the Sender } \\
\text { and the Receiver, the greater the WOM will be actively } \\
\text { sought. }\end{array}$ & $\begin{array}{l}\text { Supported at the } 90 \% \text { level } \\
\text { of confidence }(\alpha=0.10) \text {. }\end{array}$ \\
\hline H4 & $\begin{array}{l}\text { The greater the perceived risk of the service, the greater } \\
\text { the extent to which the WOM will be sctively sought by } \\
\text { the Receiver. }\end{array}$ & $\begin{array}{l}\text { Supported at the } 95 \% \text { level } \\
\text { of confidence }(a=0.05) \text {. }\end{array}$ \\
\hline HS & $\begin{array}{l}\text { The greater the Sender's expertise, the greater the extent } \\
\text { to which the WOM will be actively sought by the } \\
\text { Receiver. }\end{array}$ & $\begin{array}{l}\text { Supported at the } 90 \% \text { level } \\
\text { of confidence }(\alpha=0.10) \text {. }\end{array}$ \\
\hline H6 & $\begin{array}{l}\text { The greater the Sender's expertise, the greater the } \\
\text { influence of the Sender's WOM on the Receiver's } \\
\text { purchase decision. }\end{array}$ & $\begin{array}{l}\text { Supported at the } 95 \% \text { level } \\
\text { of confidence }(\alpha=0.05) \text {. }\end{array}$ \\
\hline H7 & $\begin{array}{l}\text { The greater the Receiver's expertise, the lesser the } \\
\text { WOM will be actively sought by the Receiver }\end{array}$ & Not supported. \\
\hline $\mathbf{H 8}$ & $\begin{array}{l}\text { The greater the Receiver's expertise, the leacer the } \\
\text { Receiver's perceived risk sasociated with the service. }\end{array}$ & $\begin{array}{l}\text { Supported at the } 95 \% \text { level } \\
\text { of confidence }(\alpha=0.05) \text {. }\end{array}$ \\
\hline H9 & $\begin{array}{l}\text { The greater the Receiver's level of expertise, the lesser } \\
\text { the Influence of the Sender's WOM on the Receiver's } \\
\text { purchuse decision. }\end{array}$ & Not supported. \\
\hline
\end{tabular}

Table 7. Summary of the hypotheses for the structural part of the model. 


\section{Chapter 5}

\section{DISCUSSION}

Each of the hypotheses will be discussed per the validation results as indicated above in Table 7.

Hypothesis 1. This hypothesis predicted that the greater the extent to which the WOM is actively sought by the Receiver, the greater the influence of the Sender's WOM on the Receiver's purchase decision. The results were in complete accordance with expectations. As seen in Figure 4, an extremely strong relationship was found between the two constructs at the 0.05 level.

Hypothesis 2. According to this hypothesis, it was expected that strong ties between the Sender and the Receiver would be more likely than weak ties to influence of the Sender's WOM on the Receiver's purchase decision. It was determined that this relationship does exist at the $10 \%$ level.

Hypothesis 3. It was expected that the extent to which WOM information is actively sought by the Receiver would increase as the tie strength between the Sender and the Receiver increases. In accordance with this expectation, the relationship was found to exist. A positive relationship which is significant at the 0.10 level of significance was attained.

Therefore a moderately positive relationship was determined. The higher the tie strength, the more the WOM would actively be sought. This result can be interpreted to mean that people (Receivers) more actively seek WOM information from others (Senders) with whom they have a relationship of some degree. That is, when people 
engage in active search for WOM, they would likely seek this information from those in which a tie connection exists.

Hypothesis 4. This hypothesis predicated that the greater the perceived risk of the service, the greater the extent to which the WOM will be actively sought by the Receiver. This relationship was substantiated at the 0.05 level.

Hypothesis 5. The hypothesis proposed that the greater the Sender's expertise, the greater the extent to which the WOM will be actively sought by the Receiver. This relationship was found to exist at the 0.10 level of significance.

Hypothesis 6. It was expected that the greater the Sender's expertise, the greater. the influence of the Sender's WOM on the Receiver's purchase decision. This relationship was determined to be very strong at the 0.05 level of significance.

Hypothesis 7. This hypothesis predicated that the greater the Receivers level of expertise, the lesser the extent to which WOM would be actively sought. Contrary to expectations, analysis indicated that there is a strong positive relationship between these two variables.

As was previously mentioned, there is a body of literature that postulates a positive relationship between knowledge (applied in this context to be a proxy for expertise) and the search for additional information regarding the product or service (Brucks 1985). Some of these studies purport that prior knowledge acts to encourage information search by facilitating the processing of new information (Punj and Staelin 1983). As Brucks (1983) indicates, "knowledge also helps the individual evaluate responses to questions, thus reducing the cognitive cost of using information and 
increasing the benefit of obtaining it, leading to greater search with increased results.

Such a hypothesis may explain the results of studies that have found a positive relationship between experience and amount of search" (p.3).

The level of search tends to be greatest among those consumers who are moderately knowledgeable about the product (or service) and least among consumers who are either extremely knowledgeable or, at the opposite extreme not at all knowledgeable. Hence, studies have resulted in the formulation of an inverted U-shaped relationship between knowledge an how actively information is sought (Bettman and Park 1980).

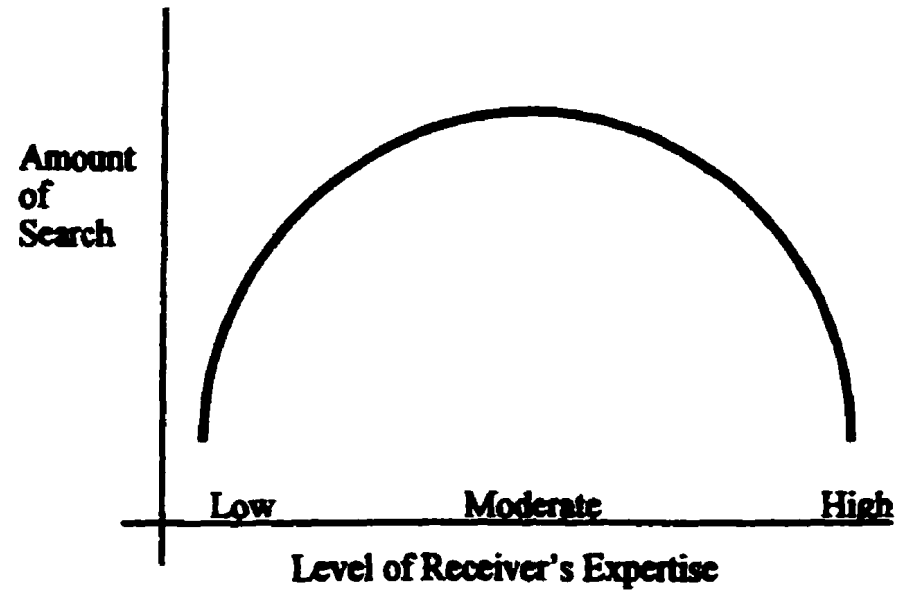

Figure 5. An inverted $U$ shaped diagram indicating that active search for information is greatest when the Receiver's expertise is rated as being moderate and least when expertise is either high or low. 
In order to determine if this occurrence is at play within this study, the mean of the responses of Receiver's expertise must be examined. Since the mean is 3.88, which falls in the middle of the scale of 1 to 7, it can be observed that respondents within the survey rated themselves as moderately knowledgeable. It can be theorized, therefore, that it is this U-shaped relationship that is representative of the existing situation within this study. It is for this reason that results indicate a positive relationship between the variables: Receiver's expertise and WOM actively sought by Receiver.

Hypothesis 8. According to this hypothesis, the greater the Receiver's expertise, the lesser the Receiver's perceived risk associated with the service. This relationship was found to exist at the 0.05 level of significance.

Hypothesis 9. This hypothesis supposed that the greater the Receiver's level of expertise, the lesser the influence of the Sender's WOM on the Receiver's purchase decision. Contrary to the expectation, however, the relationship was found to be extremely weak and therefore, not statistically significant. The directionality, however, was in accordance with the hypothesis.

\section{Summarizing Conclusions Regarding Interpersonal Variables}

Recall that the interpersonal variables in the conceptual model are tie strength and the extent to which WOM is actively sought. The findings of this study suggest that when WOM information is actively sought, it will have a greater influence on the Receiver's purchase decision than if it was not actively sought. The results also suggest that when the tie between the Sender and the Receiver is strong, the WOM information will have a significant influence on the Receiver's purchase decision. Also, statistical 
support indicating that tie strength is directly related to how actively the WOM information is sought was attained. Results indicate low strength (at the $10 \%$ level of significance) for a positive relationship between the two constructs.

\section{Summarizing Conclusions Regarding Non-interpersonal Variables}

The non-interpersonal variables within the conceptual model include Receiver's expertise, Sender's expertise and risk. The findings indicate that there exists a very strong positive relationship between Receiver's expertise and the degree of search for WOM. This relationship was attained since the majority of respondents indicated that they possessed moderate levels of expertise regarding the service being considered.

Receiver's expertise was also found to be a significant indicator of the amount of risk that he or she will perceive. The higher the expertise, the lower the risk. Expertise can be thought to decrease the perceived risk since the more that someone is knowledgeable or possesses experience, the less risk will be perceived. Additionally, the greater that risk is perceived, the more that WOM will be actively sought. People actively seek WOM information in an effort to reduce associated perceived risk.

Sender's expertise was found to be a very strong indicator of the influence on the Sender's WOM on the Receiver's purchase decision, where a significant positive relationship exists between the two constructs. When a Sender is perceived to possess a high level of expertise, the Receiver will likely attend extremely closely to the incoming WOM information. Additionally, since the Sender is perceived as being knowledgeable, there is motivation for the Receiver to actively seek information from the knowledgeable Sender. The attainment of information can be considered as being a motivating force for 
the active search for WOM information from the expert Sender.

\section{Summary of Mensurements and Salient Analytical Results}

In total 450 survey questionnaires were distributed. Returned, were 176 forms, of which 165 were usable. Those which were discarded were done so for two main reasons: incomplete, where entire sections were not completed; and erroneous information provided, where the respondent indicated product purchase vice the required services or indicated numerous choices instead of only one. In an effort to reduce the impact of problems associated with retrospective data, a cut-off point of 24 months was used. A three-step analytical process was then conducted on the remaining data set.

In summary, the following results transpired as a result of the foregoing analysis:

a. Stage 1: Following analysis using SPSS, items $\mathrm{Hl}$ and H5 were deleted from further consideration based on the desire to increase internal consistency measured by Cronbach's alpha. Based on factor analysis, only item F7 was retained from Section F for subsequent analysis. Also, item $\mathbf{G 2}$ was deleted from further consideration since it was deemed that adequate measurement of the construct could occur without this item;

b. Stage 2: Confirmatory internal reliability was conducted using LISREL8. In an effort to meet the established minimum values for error variance and overall fit $\left(a>0.6\right.$ and $\left.\mathrm{R}^{2}>0.4\right)$, items $\mathrm{H} 4$ and $\mathrm{H} 8$ were deleted; and 
c. Stage 3: Path analysis resulted in a determination of the respective loading on each path of the model. Accordingly, hypotheses were either validated where a statistically significant relationship existed or no relationship between sets of constructs existed.

As a result of the aforementioned analysis, hypotheses $\mathrm{H} 7$ and $\mathrm{H} 9$ were not validated and therefore did not result as originally postulated. Reasons for these discrepancies were explainable and were addressed above.

\section{Managerial Considerations}

It is imperative to realize that every business stimulates WOM, whether it is intentional or not. The customer ultimately has the "last word." In light of this, it is crucial that the customer be kept happy so that two principal occurrences are facilitated. Firstly, that no negative WOM is generated. Secondly, hopefully, positive WOM is created. Ultimately, therefore, businesses must do whatever it takes to keep the customer happy. Business people must also realize that they can do much to influence WOM by providing very good service (in accordance with the desires of the customers); effectively practise relationship marketing and ensure all activities are "client-centred."

In order to directly apply the conceptual model to managerial applications, a segmented approach should be used. Consider, for example, the relationship uncovered within this research which indicated the existence of a strong positive relationship between the extent to which WOM is actively sought and Receiver's expertise. Using this relationship as a basis and capitalising on it, marketers could aim at stimulating the 
transmission of positive WOM by attempting to stimulate the Receiver (secker of WOM) to actively seek WOM information on the desired service. A multi-staged framework could be used for this purpose.

A multi-staged framework could consist of initially attempting to stimulate a need or desire to attain information on the particular service. Secondly, using the aforementioned "inverted U relationship" (between search activity and expertise), an advertising campaign could seek to "move" potential customers into the "moderate" range of expertise. Per the inverted $U$ relationship, these customers could be expected to very actively seek the required information. Thus, the amount of search activity would be maximized. Thirdly, a likely source for the information could be suggested such as, "ask a friend" or mention an objective third party source such as Consumer Reports. Emphasis should be on providing the source which would likely provide the desired (most favourable) information. Lastly, since the information is highly sought, it would likely have a significant influence on the purchase intention of the Receiver. Dangers do exist in the above framework. For instance, negative WOM could have a detrimental effect on the actual likelihood of purchase.

For marketers, the thesis' findings suggest that in an effort to initiate a WOM message and increase its effectiveness, an attempt should be made to explicitly focus on tie strength perceptions between the Sender and the Receiver in their target audience. For example, if a long distance telephone service company wished to capitalise on the benefits of WOM amongst a student audience, their promotional efforts would not only reflect the attributes of the service, but also suggest potential consumers from whom 
information regarding the service could be sought. In this situation, information secking could be focussed on other student customers (as opposed to non-student customers) who are considered "friends". Suggestions to seek information from "friends" may make the construct of tie strength salient in the decision making process of these potential customers. Hence, not only do such messages suggest that Receivers actively seek information, but also suggest that this information should be sought from "friends" or Senders with whom the Receiver is likely to have a high tie strength. Business and other networks are very powerful sources of information for certain groups for example, women business owners.

WOM has direct implications on advertising. Day (1971) made a connection between WOM and advertising by attesting to the notion that positive WOM is the ultimate product success factor. Bristor (1990) also indicated that most marketers contend that when positive WOM is strong, the need for advertising is reduced. Moreover, she mentioned that influences over cognition and affect which precede behaviour, might explain the differences between advertising and WOM. Further, as Murray (1991) indicated, "knowledge of information acquisition strategies is vital to both marketing managers and scholars because [the] information search [process] is an early influential stage in the purchase decision process" (p.10-11).

Managers, marketers and all business people must appreciate the power of WOM. Still et al. (1984) state that, "if WOM is a major influence for large numbers of potential buyers, the need is for one kind of strategy and advertising approach....formulators of market strategy should keep in mind that extent to which WOM communications 
influence buying actions by members of target market segments" (p. 335).

As indicated by Amdt (1967a), "perhaps the main concern of the marketing practitioner is how to stimulate people to speak favourably of his [or her] products [or services]. In other words, he [or she] is interested in the relationship between certain marketing mix "inputs" and the output, which in this case would be word of mouth actively" (p.67). Additionally, he highlighted several key principles which might stimulate favourable WOM. These principles, he identified as: making sure that prospective communicators understand the intended message; help them to put their experience into words; and be sure that they use words which have favourable connotations.

Marketers who are involved in the formulation of an integrated market communications plan, especially for services, would be particularly interested in developing a WOM communications network. One means by which this could be achieved is by providing incentives for those who refer another to the desired and rewarded service. Community events, for example, frequently rely on WOM for publicity. In both cases, the development of positive WOM is the desired effect.

WOM is of tremendous importance to marketers bearing in mind that the success of some advertising campaigns directly relies on the generation of WOM. Therefore, they accordingly succeed or fail primarily due to the attainment or defeat of WOM support (Still et al, 1984).

WOM is a very effective medium as well as being invisible and distinct from other marketing tools, hinging on dispersal from one person to another (usually), free 
(unlike testimonials), poorly understood and requiring no special personal talent. The feature that WOM is free has potential benefit for some industries, especially since there is often an inverse relationship between the availability of advertising funds and the reliance on WOM.

WOM is a highly influential source in determining expected service, which in turn is a key element of perceived service quality (Webster 1991). Also, WOM was determined to have the strongest impact on quality expectations followed by past personal experience and lastly by advertising and sales promotion. This contention was further substantiated by Zeithaml et al. (1993), when it was reported that WOM was not only important in informing and persuading consumers about a product of service, but it also acted to actually shape consumer expectations, particularly for professional services such as medical and dental.

The study of WOM is particularly important for those services that rely upon WOM to a greater extent than those that do not. In particular, this applies to services that are difficult to evaluate before purchase of them as well as prior to when direct experience can be realized (Zeithaml and Bitner, 1996). Medical and dental care are examples of such services.

The potential impact of WOM is often overlooked and repeatedly underestimated by small businesses. Frequently, for instance, customers who are dissatisfied for whatever reason, request that their money be returned subsequent to making a purchase. Often this is denied leading to intense customer dissatisfaction and likely a resultant failure of return business. In this scenario, the business owner, or manager, fails to 
realize that, had he or she absorbed the cost of the return item, which in turn would have led to customer satisfaction and likely generated significant positive WOM. The value of this WOM would have greatly exceeded the incurred cost of returning the item. A dissatisfied customer would generate much negative WOM and thus, potentially, result in a loss of business. As Wilson (1991) states, "the rule of 3-33. For every three people willing to tell a positive story about an experience with your company, there are 33 others who will tell a horror story" (p.22). It therefore behoves businesses to strive to keep customers happy in an effort to stimulate positive WOM.

Satisfied and loyal customers are likely to spread positive WOM about a service in which they have engaged in. As was mentioned, this form of communication can be considerably more effective than paid advertising. Using this type of communication has a key benefit for the company of attracting new customers in a very inexpensive manner (Zeithaml and Bitner, 1996).

Industries use WOM for a variety of different reasons. The foregoing research has significant implications, not only to the academic community, but also to professions where WOM marketing is the primary means of advertising and referral. For example, within the medical, dental and legal professions, WOM is the major mechanism by which new business and new clients are attained.

Within a WOM environment, marketers would be greatly aided by an appreciation and an understanding of the inner workings and relationships between the constructs of Receiver's and Sender's expertise, Receiver's perceived risk, tie strength and the extent to which WOM is actively sought by the Receiver, in relation to their effects on the 
influence of the Sender's WOM on the Receiver's purchase decision.

Should WOM be stimulated by astute marketers, in a particular campaign, an understanding of expertise would be needed in order to expand the Sender's expertise (if an attempt was being made to increase the expertise of opinion leaders) or stimulate Receivers to actively seek WOM from Senders. Knowing the extent to which the strength of tie could positively affect the influence of the WOM on the Receiver's purchase decision could prove valuable if this element is targeted in a campaign.

\section{Limitations and Avenues for Future Research}

Retrospective data is recognized as being a limitation of the study. However, various steps were taken in order to reduce the negative impact of this type of data. These were previously discussed and will therefore not be addressed again.

A key limitation of the study is the issue of applicability of findings to the general population. Due to many of the homogeneous characteristics of the military community, there may be concerns regarding potential projections of findings to the general population. As such, the results may not be applicable to service purchase decision contexts amongst various other audiences.

Another possible limitation concerns the responses as given by subjects. Within the questionnaire, subjects related all responses to one specific instance of receipt of WOM information. From this, generalization is made to believe that this applies to all service encounters in which WOM was used. Therefore, the question is: can this actually be generalized to all service purchase situations in which WOM was an active ingredient? 
The power of WOM as it relates to advertising is often mentioned in the literature. It is a frequent postulation that WOM is more powerful than formal advertising. What is necessary, therefore, is the need to more fully examine the synergistic effect of advertising and WOM (Bristor 1990). Additionally, extending this notion, what also is needed is to examine "the effects of word of mouth on cognitions and affect" (Bristor 1990 , p. 58). 


\section{Chapter 6}

\section{CONCLUSION}

The foregoing discussion reflects an attempt to provide meaningful insights into the understanding of WOM processes within a services purchase decision context.

The processes of WOM as they influence service purchase decisions are powerful and complex, however, not well understood. The examination of WOM processes is founded in the basic communication model. Key constructs such as expertise, risk, tie strength and the extent to which the WOM message is sought, are likely highly influential in determining the overall influence that WOM has on services purchase decision. 
Appendix A - Questionnaire 
4 November 1998

Dear Participant:

It is requested that you complete the attached questionnaire, which should take no longer than 10 minutes to complete. Participation is completely voluntary and all responses are strictly confidential.

As part the process of fulfilling the requirements for my Masters of Business Administration (MBA) degree, I am conducting research into the influence of information received via word-of-mouth, in terms of service purchase decision making. It is thought that this (word-of-mouth) could be influential in the way that people select service providers such as dentists, lawyers, vehicle mechanics, hair stylists, etc. My supervisor for this thesis is Dr Harvir Bansal from the Faculty of Business Administration, University of New Brunswick.

Your contribution to this research effort is greatly appreciated. Should you have any questions regarding this thesis, please do not hesitate to contact me at 446-6952. Again, thank you for your assistance.

//original signed by//

Peter Voyer

MBA Student

Enclosure: 1 


\title{
Section A
}

Please complete the following questions:

A1. Today's date

A2. Date (Month and Year) of arrival at your present location

\section{Section B}

This questionaaire is designed to examine the procesces of word-of-mouth marketing within a servicepurchase context. Word-of-month communication is informal and takes place between two or more people, none of whom represent a commerchal selling sonree that would gatin direethy from the sale of something. Word-of-mouth inplies personal, or face to face, commonication, althengh it anay also take place in a telephone conversation or within the coutext of a chat group on the Internet.

Please select only one (1) service from the following succeoted lioth in which you attained word-of-month information about. This should be a service on which you reeetved hiformation fren another person prior to purchasing it. Only one (1) service should be eircled. If none of the suesested services are appropriate, indicate one of your ehoice next to the "Other" space.

\section{Child Care}

Dentist

Legal services

Optometrist

\section{Hair Stylist}

Auto Repair (mechanic)

Television repair

Bank (financial service)
Veterinary service

Favorite restaurant

Truvel agent

Child's tutor service

Other

Please consider this service throughout the questionnaire since all quations refor to it

\section{Section C}

Please consider your relationship with the person from whom you attained the word-of-mouth information about the service that you seleeted above in Part B, before you purchesed the semice. For each question eirele the number that best deseribes your resposece. There are no right or wrones reapoince We are onfy interested in your pereeption the strength of che de between you (the Recelver) and the Sender of the wordof-mouth information, before you purehased the service.

C1. How would you have described your relationship with the Sender of wond-of-mouth message?

$\begin{array}{lllllll}1 & 2 & 3 & 4 & 5 & 6 & 7\end{array}$

Not close at all

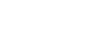

12

$46-6$

\author{
Extracodinurily close
}


C2. How likely were you to have shared a personal confidence with the seader of word-of-mouth?

$\begin{array}{llllllll}\text { Very Unlikely } & 1 & 2 & 3 & 4 & 5 & 6 & 7 \\ \text { Very Likely }\end{array}$

C3. How likely were you to have extended everyday (as opposed to emengency) assistance to the sender of word-of-mouth?

$\begin{array}{llllllll}\text { Very Unlikely } & 1 & 2 & 3 & 4 & 5 & 6 & 7 \\ \text { Very Likely }\end{array}$

C4. How likely were you to have spent a free aftemoon with the sender of word-of-mouth?

$\begin{array}{llllllll}\text { Very Unlikely } & 1 & 2 & 3 & 4 & 5 & 6 & 7 \\ & & & & & & \text { Very Likely }\end{array}$

\section{Section D}

Please consider the experdise of che Sender of the word-of-mouth information about the service that you selected above in Part B. For each statement eircle the number that best deseribes your feelinger. There are no right or wrong responses. We are ouly interested in your pereeption of the expertice of the Seader of word-of-mouth information on the service that you selected in Part B.

D1. Please rate the Sender of the word-of-mouth information in terms of his/her expertise on the service, as you perceived it at the time that you received the information.

\begin{tabular}{|c|c|c|c|c|c|c|c|}
\hline Dia. & Not Knowledgeable & 2 & 3 & 4 & 5 & 6 & $\begin{array}{l}7 \\
\text { Knowledgeable }\end{array}$ \\
\hline D1b. & Not Competent & 2 & 3 & 4 & 5 & 6 & $\begin{array}{l}7 \\
\text { Competent }\end{array}$ \\
\hline Dle. & Not an Expert & 2 & 3 & 4 & 5 & 6 & $\begin{array}{l}7 \\
\text { Expert }\end{array}$ \\
\hline D1d. & Not Trained & 2 & 3 & 4 & 5 & 6 & $\begin{array}{l}7 \\
\text { Trained }\end{array}$ \\
\hline D1e. & Not Experienced & 2 & 3 & 4 & 5 & 6 & $\begin{array}{l}7 \\
\text { Experienced }\end{array}$ \\
\hline
\end{tabular}

\section{$\underline{\text { Section E }}$}

Please consider your expertise, that is, the expertise of the Recelver, of the word-of-mouth information about the service that you selected above in Part B. For enel statement circle the mumber that beat deseribes your feelings. There are no rifht or wrong responses. We are only interested in your perception of your expertise of the service that you selected in Part $B$. 
E1. How would you have rated your expertise regarding this service at the time that you received the word-ofmouth information?

\begin{tabular}{|c|c|c|c|c|c|c|c|c|}
\hline E1a. & $\begin{array}{l}\text { Knew very little } \\
\text { about it }\end{array}$ & 1 & 2 & 3 & 4 & 5 & 6 & $\begin{array}{l}7 \\
\text { Knew very much } \\
\text { about it }\end{array}$ \\
\hline E1b. & Inexperienced & 1 & 2 & 3 & 4 & 5 & 6 & $\begin{array}{l}7 \\
\text { Experienced }\end{array}$ \\
\hline E1c. & Uninformed & 1 & 2 & 3 & 4 & 5 & 6 & $\begin{array}{l}7 \\
\text { Informed }\end{array}$ \\
\hline EId. & Novice Buyer & 1 & 2 & 3 & 4 & 5 & 6 & $\begin{array}{l}7 \\
\text { Expert Buyer }\end{array}$ \\
\hline
\end{tabular}

\section{Section F}

During the purchase of any service, there $i s$ always a poseibillty that a consumer will choose the wrons service provider. Thus, there is a certain amount of risk aseochted with the purchase of a service. Piease answer the following questions in that context for the purehase of the service that you selected in Part $B$.

For each question circle the namber that best describes your response There are no ridht or wroes. responses. We are only interested in your pereeption rible

F1. How financially risky was the decision to purchase this service (i.e., how certain were you of the final cost of the service)?

$\begin{array}{llllllll}\text { Not risky at all } & 1 & 2 & 3 & 4 & 5 & 6 & \begin{array}{l}7 \\ \text { Extremely risky }\end{array}\end{array}$

F2. How risky was the decision in terms of the service performance (i.e., how certain were you that the service would be performed as appropriately as you had initially thought)?

$\begin{array}{llllllll}\text { Not risky at all } & 1 & 2 & 3 & 4 & 5 & 6 & 7 \\ & & & & & & \text { Extremely risky }\end{array}$

F3. How risky was the decision in terms of convenience (i.e., how did you perceive the likelihood of losing time and effort in order to achieve satisfaction with the service)?

$\begin{array}{lllllllll}\text { Not risky at all } & 1 & 2 & 3 & 4 & 5 & 6 & 7 \\ & & & & & & \text { Extremely risky }\end{array}$

F4. How risky was the purchase decision in terms of physical harm (i.e., what was the likelihood that you could have sustained harm or risked safety or danger)?

$\begin{array}{llllllll}\text { Not risky at all } & 1 & 2 & 3 & 4 & 5 & 6 & 7 \\ & & & & & & & \text { Extremely risky }\end{array}$


F5. How risky was the purchase decision in terms of psychological harm (i.e., was there a possibility that you could have lost self-image )?

$\begin{array}{llllllll}\text { Not risky at all } & 1 & 2 & 3 & 4 & 5 & 6 & 7 \\ & & & & & & \text { Exdremely risky }\end{array}$

F6. How risky was the purchase decision in terms of social harm (i.e., was there a possibility that your friends and relatives would have thought less highly of you)?

$\begin{array}{llllllll}\text { Not risky at all } & 1 & 2 & 3 & 4 & 5 & 6 & \begin{array}{l}7 \\ \text { Extremely risky }\end{array}\end{array}$

F7. What was your perception of the overall risk associated with the decision to purchase this particular service?

$\begin{array}{llllllll}\text { Not risky at all } & 1 & 2 & 3 & 4 & 5 & 6 & \begin{array}{l}7 \\ \text { Extremely risky }\end{array}\end{array}$

\section{Section G}

Please consider how actively you sought the wond-of-mouth information regarding the service that you selected in Part B above. For the question cirele the unmber that best deseribes your response. There are no right or wrong responses. We are ouly interested in how setively you sought the word-of-month information.

G1. You explicitly requested the Sender to provide information which would help in your service purchase decision.

$\begin{array}{llllllll} & 1 & 2 & 3 & 4 & 5 & 6 & 7 \\ \text { Strongly Disagree } & & & & & & \text { Strongly Agree }\end{array}$

G2. You made numerous attempts to gather information from the Sender of word-of-mouth message.

Strongly Disagree

$\begin{array}{llllll}2 & 3 & 4 & 5 & 6 & 7 \\ & & & & \text { Strongly Agree }\end{array}$

\section{Section H}

Please consider the infuence that the Seader of the word-of-month information had on you, the Recelver of the message. Remember that this is for the service that you had selected above in Part B. For each statement circle the number that best deseribes your feeling. There are no right or wrong responses. We are only interested in your pereeption of the infinence of the Sender of the word-of-month message on your purchase decision.

H1. The Sender provided little new information that helped you with your purchase decision.

$\begin{array}{llllllll} & 1 & 2 & 3 & 4 & 5 & 6 & 7 \\ \text { Strongly Disagree } & & & & & & \text { Strongly Agree }\end{array}$


H2. The Sender had significant influence on your choice about buying the service.

$\begin{array}{llllllll} & 1 & 2 & 3 & 4 & 5 & 6 & 7 \\ \text { Strongly Disagree } & & & & & & \text { Strongly Agree }\end{array}$

H3. The Sender mentioned some things that helped you with your purchase decision.

$\begin{array}{llllllll} & 1 & 2 & 3 & 4 & 5 & 6 & 7 \\ \text { Strongly Disagree } & & & & & & \text { Strongly Agree }\end{array}$

H4. The Sender provided some different ideas from other sources that helped you with your purchase decision

$\begin{array}{llllllll} & 1 & 2 & 3 & 4 & 5 & 6 & 7 \\ \text { Strongly Disagree } & & & & & & \text { Strongly Agree }\end{array}$

H5. The Sender really did not change your mind about buying the service.

$\begin{array}{llllllll} & 1 & 2 & 3 & 4 & 5 & 6 & 7 \\ \text { Strongly Disagree } & & & & & & \text { Strongly Agree }\end{array}$

H6. The Sender really helped you make a decision about buying the service.

$\begin{array}{lllllllll} & 1 & 2 & 3 & 4 & 5 & 6 & 7 \\ \text { Strongly Disagree } & & & & & & \text { Strongly Agree }\end{array}$

H7. How much influence do you think the Sender had on the service that you actually bought.

$\begin{array}{cccccccc}\text { Very little Influence } & 2 & 3 & 4 & 5 & 6 & 7 \\ \text { Complete Influence }\end{array}$

H8. How much influence do you think the Sender had on the features you looked for in the service.

$\begin{array}{cccccccc}1 & 2 & 3 & 4 & 5 & 6 & 7 \\ \text { Very little Influence } & & & & & & \text { Complete Influence }\end{array}$

\section{Section I}

Please consider your involvement with the purchase of the service that you had seleeted in Part B. For each statement eircle the aumber that best describes your feelings. There are so right or wrong responses. We are only interested in your perception of your involvement with the purehase.

I1. Please rate the process of choosing the service selected in Part B on each of the following scales.

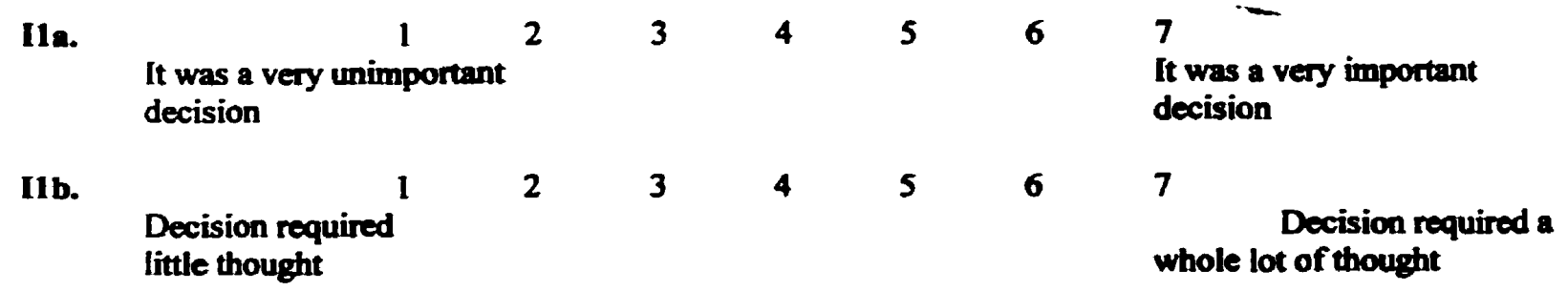


I1c.

$\begin{array}{llllll}1 & 2 & 3 & 4 & 5 & 6 \\ \text { Little to lose if you } & & & & & \\ \text { had chosen the wrong } \\ \text { service provider }\end{array}$

7

A lot to lose if you had chosen the wrong service provider

\section{Section J}

The following questions are for statiotical purposes only.

J1. Your gender?

$\mathbf{M}$

$\mathbf{F}$

J2. Your age? years

J3. What is the highest level of education that you have completed?
a. Did not complete high school
b. High school graduate
c. Technical of community college graduate
d. Undergraduate university degree
e. Post-graduate university degree

J4. Which of the following income brackets do you fall in?
a. Less that $\$ 20,000$
b. $\quad \$ 20,000-\$ 39,999$
c. $\quad \$ 40,000-\$ 59,999$
d. $\$ 60,000-\$ 80,000$
e. Above $\$ 80,000$

J5. Which of the following household income brackets do you fall in?
a. Less that $\$ 20,000$
b. $\quad \$ 20,000-\$ 39,999$
c. $\quad \$ 40,000-\$ 59,999$
d. $\quad \$ 60,000-\$ 80,000$
e. $\quad \$ 80,000-\$ 99,999$
f. Above $\$ 100,000$

Thank you very much for your participation, it is greally appreciaced 


\section{BIBLIOGRAPHY}

Alba, Joseph W. and Wesley J. Hutchinson (1987), "Dimensions of Consumer Expertise," Journal of Consumer Research, 13 (March), 411 -54.

Arndt, Johan (1967a), Word of Mouth Advertising: A Review of the Literature, New York: Advertising Research Federation Inc.

Andt, Johan (1967b), "Role of Product-Related Conversations in the Diffusion of a New Product," Journal of Marketing Research, 4 (August), 291-295.

Amdt, J.A. (1968), "Selective Process in Word-of-Mouth," Journal of Advertising Research, 8, 19-22.

Bagozzi, R.P. and Y. Yi (1988), “The Self-Regulation of Attitudes, Intentions and Behavior," Social Psychology Quarterly, 55 (2), 178-204.

Bayus, Barry L. (1985), "Word-of-Mouth: The Indirect Effects of Marketing Efforts," Journal of Advertising Research, 25 (June/July), 31-39.

Bentler, P.M. and G. Speckart (1990), "Models of Attitude-Behavior Relations," Psychological Review, 86, 452-464.

Bettman, James R. and C. Whan Park (1980), "Effects of Prior Knowledge and Experience and Phase of the Choice Process on Consumer Decision Processes: A Protocol Analysis," Journal of Consumer Research, 7 (December), $234-48$.

Bitner, Mary Jo (1990), "Evaluating Service Encounters: The Effects of Physical Surroundings and Employee Responses," Jowrnal of Marketing, 54 (April), 69-90.

Bitner, Mary Jo (1991), "The Evolution of the Services Marketing Mix and Its Relationship to Service Quality," in Service Quality: Multi disciplinary and Multinational Perspectives, eds, Brown, Gummeson, Edvardson and Gustavson, Lexington Books, 2337.

Bloch, Peter, Daniel Sherrell and Nancy Ridgway (1986), "Consumer Search: An Extended Framework," Journal of Consumer Research, 13 (June), 119-26.

Bollen, K.A. (1989), Structural Equations With Latent Variables, Wiley, New York, NY.

Bristor, Julia M. (1990), "Enhanced Explanations of Word of Mouth Communications: The Power of Relationships," Research in Consumer Behavior, 4, 51-83. 
Brown, Jacqueline Johnson and Peter H. Reingen (1987), "Social Ties and Word-ofMouth Referral Behavior," Journal of Consumer Research, 14 (Docember), 350-62.

Browne, M.W. and R. Cudeck (1993), "Alternative Ways of Assessing Model Fit," in Testing Structural Equation Models, Eds. Kenneth Bollen and J. Scott Long, Sage Publications, Newbury Park, CA.

Brucks, Merrie (1985), "The Effects of Product Class Knowledge on Information Search Behavior," Journal of Consumer Research, 12 (June), 1-16.

Calder, B.J., L.W. Phillips and A.M. Tybout (1981), "Designing Research for Application," Journal of Consumer Research, 8 (September), 197-207.

Carman, James (1990), "Consumer Perceptions of Service Quality: An Assessment of SERVQUAL Dimensions," Journal of Retalling, 66 (Spring), 33-55.

Cook, Thomas and Donald Campbell (1975), "The Design and Conduct of Experiments and Quasi-Experiments in Field Settings," in Handbook of Industrial and Organizational Research. Ed. Martin Dunnette, Rand McNally \& Co., Chicago. II.

Cunningham, M. Scott (1965) "Perceived risk as a Factor in Product-Oriented Work-ofMouth Behaviour: A First Step" in L.G. Smith, ed., Reflections on Progress in Marketing. Proceedings of the 1964 Educators Conference, Chicago: American Marketing Association, 229-39.

Charlett, D. and R. Garland (1995), "How Damaging is Negative Word-of-Mouth?," Marketing Bulletin, 6 (May), 1-9.

Day, G.S. (1971), “Attitude Change, Media and Word of Mouth,” Journal of Advertising Research, 11 (6), 31-40.

Dichter, E. (1966), "How Word-of-Mouth Advertising Works," Harvard Business Review, November-December, 147-66.

Duhan, D.F., S.D. Johnson, J.B. Wilcox and G.D. Harrell (1997), "Influences on Consumer Use of Word-of-Mouth Recommendation Sources," Journal of the Academy of Marketing Science, 25 (4), 283-95.

Duncan, Tom and Sandra E. Moriarty (1998), “A Communication-Based Marketing Model for Managing Relationships," Journal of Marketing, 62 (April), 1-13. 
Feldman, S.P. and M.C. Spencer (1965), "The Effect of Personal Influence in the Selection of Consumer Services," Proceedings of the Fall Conference of the American Marketing Association, ed. Peter D. Bennet, Chicago: American Marketing Association, 440-52.

Financial Post (1997), "Making a Market through Work-of-Mouth: How Japanese Companies Are Staying One Step Ahead of The Country's Materialistic Teens," Sep 18, 77.

Fornell, C. and D. Larker (1981), "Evaluating Structural Equation Models with Unobservable Variable and Measurement Error," Journal of Marketing Research, 18, 3950.

Frenzen, Jonathan K. and Harry L. Davis (1990), "Purchasing Behavior in Embedded Markets," Journal of Consumer Research, 17 (June), 1-12.

Frenzen, Jonathan K. and K. Nakamoto (1993), "Structure, Cooperation, and the Flow of Market Information," Journal of Consumer Research, 20 (December), 360-75.

Friestad, M. and P. Wright (1994), "The Persuasion-Knowledge Model: How People Cope With Persuasion Attempts," Journal of Consumer Research, 21 (June), 1-31.

Furse, David, Girish Punj and David Stewart (1984), "A Typology of Individual Search Strategies Among Purchasers of New Automobiles," Journal of Consumer Research, 10 (March), 417-31.

Gilly, Mary C., John L. Graham, Mary Finley Wolfinbarger and Laura J. Yale (1998), “A Dyadic Study of Interpersonal Information Search," Journal of the Academy of Marketing Science, 26, 83-100.

Granovetter, S. Mark (1973), "The Strength of Weak Ties," American Journal of Sociology, $78(6), 1360-80$.

Hair, J.F. Jr., R.E. Anderson, R.L. Tatham and W.C. Black (1995), Multivariate Data Analysis, Englewood Cliffs, NJ.

Henricks, Mark (1998), "Spread the Word," Entrepreneur, 120-25.

Herr, P.M., F.R. Kardes and J. Kim (1991), "Effects of Word-of-Mouth and ProductAttribute Information on Persuasion: An Accessibility-Diagnosticity Perspective," Journal of Consumer Research, 17 (March), 454-462.

Iacobucci, Dawn and Nigel Hopkins (1992), "Modelling Dyadic Interactions and Networks in Marketing," Journal of Marketing Research, 24 (February), 5-17. 
Johnson, E. and J.E. Russco (1984), "Product Familiarity and Learning New Information," Journal of Consumer Research, 11(June), 542-50.

Joreskog, Karl G. and Dag Sorbom (1993), LISREL8.12a: Structural Equation Modelling with the SIMPLIS Command Language, Scientific Software, Chicago, Ii.

Keaveney, Susan M. (1995), "Customer Switching Behavior in Service Industries: An Exploratory Study," Journal of Marketing, 59 (April), 71-82.

Kiel, Geoffrey and Roger Layton (1981), "Dimensions of Consumer Information Seeking Behavior," Journal of Marketing Research, 18 (May), 233-39.

Lasswell, Harold D. (1948). "The Structure and Function of Communication in Society" in The Communication of Ideas, L. Bryson, ed. New York: Harper, 37-51.

Marney, Jo, (1998), "Selling in Tongues," Marketing Magazine, 14.

Marsh, H.W., (1994), "Confirmatory Factor Analysis Models of Factor Invariance: A Multifaceted Approach," Structural Equation Modelling, 1 (1), 5-34.

McDonald, R.P. and H.W. Marsh (1990), "Choosing a Multivariate Model: Noncentrality and Goodness of Fit," Psychology Bulletin, 107, 247-82.

Mitchell, Andrew A. and Peter A. Dacin (1996), "The Assessment of Alternative Measures of Consumer Expertise," Journal of Consumer Research, 23 (December), 21939.

Mishra, S., U.N. Umesh and D.E. Stem (1993), "Antecedents of the Attraction Effect: An Information-Processing Approach," Journal of Marketing Research, 30 (August), $331-49$.

Money, R. Bruce, Mary C. Gilly and John L. Graham (1998), 'Explorations of National Culture and Word-of-Mouth Referral Behavior in the Purchase of Industrial Services in the United States and Japan", Joumal of Marketing, Vol 62 October, 76-87.

Murray, Keith B. (1991), "A Test of Service Marketing Theory: Consumer Information Acquisition Activities," Journal of Marketing, 55 (January), 10-15.

Murray, Keith B. and John L. Schlacter (1990), "The Impact of Services versus Goods on Consumers' Assessment of Perceived Risk and Variability," Journal of the Academy of Marketing Science, 18 (1), 51-65.

Netemeyer, G. Richard and William O. Bearden (1992), "A Comparative Analysis of Two Models of Behavioral Intention," Journal of the Academy of Marketing Science, 20 (1), 49-59. 
Nunnally, J.C. (1978), Psychometric Theory, $2^{\text {ed }}$ ed., McGraw-Hill Book Company, New York, New York.

Punj, G.N. and R. Staelin (1983), “A Model of Consumer Information Search Behavior for New Automobiles," Journal of Consumer Research, 9, March, 366-80.

Rogers, E.M. (1983), Diffusion of Innovations, New York: Free Press.

Rudd, J., F.J. Kohout (1983), "Individual and Group Consumer Information Acquisition in Brand Choice Situations," Journal of Consumer Research, 10 (December), 303-9.

Salisbury, W.D., A. Gopel and W.W. Chin (1996), "Are We All Working from the Same Script? Developing an Instrument to Measure Consensus on the Appropriation of an Electronic Meeting System," in Proceedings of the Twenty-Ninth Anmual Howaii International Conference on System Sciences, Eds. J.F.Nunmaker Jr. and R.H. Sprague Jr., 3, 13-23.

Schiffman, Leon G. and Leslie Lazar Kanuk (1997), Consumer Behoviour, $6^{\text {th }}$ ed, Upper Saddle River. New Jersey, USA.

Silverman, George (1997), "Harvesting the Power of Word of Mouth," Potentials in Marketing, 14-16.

Smith, P., C. Berry and A. Pulford (1997), Strategic Marketing Communications New Ways to Build and Integrate Communications, Kogan Pape, London, UK.

Smith, R.E. and W.R. Swinyard (1982), "Information Response Models: An Integrated Approach," Journal of Marketing, 46 (Winter), 81-93.

Solomaon, Micheal R., C. Surprenant, J.A. Czepiel and E.G. Gutman (1985), “A Role Theory Perspective on Dyadic Interactions: The Service Encounter," Journal of Marketing, 49 (Winter), 99-111.

Steiger, J. (1990), "Structural Model Evaluation and Modification: An Interval Estimation Approach," Multivariate Behavioral Research, 25,173-80.

Still, Richard R., James H. Bames Jr. and Mark E. Kooyman (1984), "Word-of-mouth Communication in Low-risk Product Decisions," International Journàl of Advertising, 3, 335-345.

Taylor, S. and P.A. Todd (1995), "Understanding Information Technology Usage: A Test of Competing Models," Information Systems Research, 6 (June), 144-76. 
Weaton, B., B. Muthen, D. Alwin and G. Summers (1977), “Assessing Reliability and Stability in Panel Models," in Sociological Methodology, D.R. Heise, ed. San Francisco: Jossey-Bass, 84-136.

Webster, Cynthia (1991), "Influences upon Consumer Expectations of Services," The Journal of Services Marketing, 5 (Winter), 5-17.

Weitz, Barton A. (1981), "Effectiveness in Sales Interactions: A Contingency Framework," Journal of Marketing, 45 (Winter), 85-103.

Wilson, Jerry R. (1991), Word of Mouth Marketing, John Wiley \& Sons, Inc., New York, USA.

Zeithaml, Valarie A. (1981), "How Consumer Evaluation Processes Differ Between Goods and Services," in Marketing of Services, J.H. Donnelly and W.R. George (eds.), Chicago: American Marketing Association, 186-90

Zeithaml, Valerie A., Leonard L. Berry and A. Parasuraman (1993), "The Nature and determinants of Consumer Expectations of Service," Journal of the Academy of Marketing Science, 21 (1), 1-12.

Zeithaml, Valarie A., Mary Jo Bitner (1996), Services Marketing, McGraw-Hill Co., New York, USA, 60-62. 